Article

\title{
Experimental Investigation of Desiccant Dehumidification Cooling System for Climatic Conditions of Multan (Pakistan)
}

\author{
Muhammad Aleem ${ }^{1}$, Ghulam Hussain ${ }^{1,2}$, Muhammad Sultan ${ }^{1, * \mathbb{D}}$, Takahiko Miyazaki ${ }^{3,4, *}$, \\ Muhammad H. Mahmood ${ }^{1}$, Muhammad I. Sabir ${ }^{2}$, Abdul Nasir ${ }^{5}$, Faizan Shabir 1,6 \\ and Zahid M. Khan ${ }^{1}$
}

1 Department of Agricultural Engineering, Bahauddin Zakariya University, Multan 60800, Pakistan; muhammadaleem189@gmail.com (M.A.); aaeamri@gmail.com (G.H.);

hamidmahmood@bzu.edu.pk (M.H.M.); faizan.shabir.sial@gmail.com (F.S.); zahidmk@bzu.edu.pk (Z.M.K.)

2 Agricultural Mechanization Research Institute (AMRI), Old Shujabad Road, Multan 60800, Pakistan; misabar786@gmail.com

3 Faculty of Engineering Sciences, Kyushu University, Kasuga-koen 6-1, Kasuga-shi, Fukuoka 816-8580, Japan

4 International Institute for Carbon-Neutral Energy Research (WPI-I2CNER), Kyushu University, 744 Motooka, Nishi-ku, Fukuoka 819-0395, Japan

5 Department of Structures and Environmental Engineering, Faculty of Agricultural Engineering \& Technology, University of Agriculture, Faisalabad 38000, Pakistan; awan312@yahoo.com

6 Department of Agricultural Engineering, Khwaja Fareed University of Engineering \& Information Technology, Rahim Yar Khan 64200, Pakistan

* Correspondence: muhammadsultan@bzu.edu.pk (M.S.); miyazaki.takahiko.735@m.kyushu-u.ac.jp (T.M.); Tel.: +92-333-6108888 (M.S.)

Received: 23 August 2020; Accepted: 20 October 2020; Published: 22 October 2020

\begin{abstract}
In this study, experimental apparatus of desiccant dehumidification was developed at lab-scale, using silica gel as a desiccant material. Experimental data were obtained at various ambient air conditions, while focusing the climatic conditions of Multan (Pakistan). A steady-state analysis approach for the desiccant dehumidification process was used, and thereby the slope of desiccant dehumidification line on psychrometric chart $\left(\phi^{*}\right)$ was determined. It has been found that $\phi^{*}=0.22$ in case of silica gel which is lower than the hydrophilic polymeric sorbent, i.e., $\phi^{*}=0.31$. The study proposed two kinds of systems, i.e., (i) standalone desiccant air-conditioning (DAC) and (ii) Maisotsenko-cycle-assisted desiccant air-conditioning (M-DAC) systems. In addition, two kinds of desiccant material (i.e., silica gel and hydrophilic polymeric sorbent) were investigated from the thermodynamic point of view for both system types, using the experimental data and associated results. The study aimed to determine the optimum air-conditioning (AC) system type, as well as adsorbent material for building AC application. In this regard, perspectives of dehumidification capacity, cooling capacity, and thermal coefficient of performance (COP) are taken into consideration. According to the results, hydrophilic polymeric sorbent gave a higher performance, as compared to silica gel. In case of both systems, the performance was improved with the addition of Maisotsenko cycle evaporative cooling unit. The maximum thermal COP was achieved by using a polymer-based $\mathrm{M}$-DAC system, i.e., 0.47 at $70^{\circ} \mathrm{C}$ regeneration temperature.
\end{abstract}

Keywords: desiccant dehumidification; silica gel; polymer; air-conditioning; Maisotsenko cycle; performance evaluation; Pakistan 


\section{Introduction}

Air-conditioning systems (ACS) are mainly used to maintain a comfortable/favorable zone in a controlled environment by manipulating temperature and relative humidity. Heating, cooling, humidification-dehumidification and ventilation are some of the modes of the ACS which correspond to the climatic conditions and the required application of air-conditioning (AC) [1]. Depending upon the type of the AC application and the climatic conditions, multiple ACS modes could be applied [2]. In addition, different $A C$ applications require particular ranges of temperature and relative humidity [3-6]. Conventionally, vapor compression air-conditioning (VCAC) systems are used to condition the environment, which primarily use hydrochlorofluorocarbons (HCFCs) and hydrofluorocarbons (HFCs) as refrigerant, endorsing environmental degradation and high energy consumption [3]. Consequently, the VCAC systems contribute to global warming (GW) due to carbon dioxide $\left(\mathrm{CO}_{2}\right)$ emissions [7]. Alternatively, the heat driven adsorption/absorption-based environment friendly ACS are in practical use [2,8]. In ACS, $30-40 \%$ of overall energy is used by buildings throughout the world, i.e., approximately half of the total energy consumption $[9,10]$. In addition, heating, ventilation, and air-conditioning (HVAC) systems consume $50 \%$ of the entire building energy [11]. Therefore, environment friendly and least-energy-consumptive cooling systems are promising for AC. Evaporative cooling systems are environment friendly and least-energy-consumptive option for building AC load management.

Evaporative cooling (EC) is a well-known and old cooling process that uses the water evaporation to lower the temperature of air. These cooling systems include direct evaporative cooling (DEC), indirect evaporative cooling (IEC), Maisotsenko cycle, i.e., M-cycle evaporative cooling systems (MEC) and M-cycle based indirect evaporative cooling (M-IEC) [7]. DEC is the simplest type of EC system in which the air comes into direct contact with water's surface to decrease its temperature. It increases the humidity of the air by using the latent heat of water [12]. In term of temperature depression, DEC has around $70 \%$ to $95 \%$ effectiveness but the main downside of DEC is an excessive amount of humidification because the water vapors constantly disperse in the air till saturation occurs [13]. The IEC is a system in which heat and mass transfer takes place without adding moisture to reduce the temperature of primary/ambient air. The IEC system comprises of a dry channel and a wet channel. [14]. Cooling in wet channel has a psychrometric limitation to wet-bulb temperature (i.e., through direct evaporative cooling); therefore, the cooling in dry channel is dependent on (and is limited to) sensible heat transfer between the dry and wet channel (i.e., wet-bulb temperature of the air in wet channel). Hence, wet-bulb effectiveness $\left(\varepsilon_{\mathrm{wb}}\right)$ can be used to define the performance of the IEC system on the basis of sensible cooling. Therefore, the IEC system can reduce the temperature down to the wet-bulb temperature, and its wet-bulb effectiveness ranges from 0.5 to $0.65[15,16]$. The drawback of the IEC system is low wet-bulb effectiveness, as compared to the DEC system due to less sensible heat transfer between the channel walls [17]. However, the extract air from an air-conditioned environment can be used to perform DEC, to increase the wet-bulb effectiveness.

Maisotsenko cycle (M-cycle) conception was proposed as early as 1976, by Maisotsenko and his colleagues in the Soviet Union, via patent numbers SU979796 and SU620745 [7]. M-cycle evaporative cooling (MEC) is a system in which ambient air is subjected to a thermodynamic process in which air-available psychrometric renewable energy is used to reduce the ambient air temperature. It extracts energy from the surrounding air by using the latent heat of evaporation phenomena [18]. Two thermodynamic processes create the cooling effect in the MEC system: evaporative cooling and heat transfer in which the ambient air almost approaches the temperature of dew point instead of the temperature of wet bulb [19-22]. M-cycle air-conditioning (MAC) systems provide sensibly cooled air and saturated hot air simultaneously [3,23,24]. In particular, the MAC system could potentially be capable of reducing energy consumption, and uses relatively less energy than the VCAC systems [25-27]. The MAC system is a dedicated outside air system which utilizes fresh ambient air to provide cool air unlike the VCAC which require mechanical energy [28-30]. The evaporative cooling with the VCAC system has been utilized in the literature, to attain the required level of AC [14,31-34]. 
In addition, several experimental and theoretical studies have been performed to achieve the necessary temperature and humidity conditions for evaporative cooling systems [35-42]. However, the key limitation of evaporative cooling technologies (DEC, IEC, and MEC) is that it cannot be effectively implemented in regions where the moisture content in the air is comparatively high $[1,6]$. Therefore, to overcome this limitation, evaporative cooling systems coupled with desiccant dehumidification units could be a viable AC option for such regions.

Desiccant air-conditioning (DAC) system contains a dehumidifying component (desiccant) to dehumidify the process air. Owning to the difference in vapor pressure, a desiccant is a substance that can adsorb moisture from the air onto its surface. Desiccant materials are used in the AC system in both solid and liquid forms. Silica gel, activated aluminum composite adsorbents, and synthetic zeolite are widely used as solid desiccants. Lithium chloride $(\mathrm{LiCl})$ and lithium bromide ( $\mathrm{LiBr})$ are liquid desiccants that are widely used. However, the major drawbacks of liquid desiccants are corrosiveness and crystallization $[43,44]$. Some recently developed composite materials that can perform even better are also available [45]. Due to their water attraction capability, the DAC systems are critical in applications where relative humidity $(\mathrm{RH})$ control is mandatory. For humid climates, the DAC system is an energy-efficient and sustainable solution [3]. For temperature and humidity regulation, the DAC is incorporating desiccant dehumidification and evaporative cooling. The sensible and latent load of air can be treated simultaneously by the DAC system, which makes the DAC system versatile. The DAC is an environment-friendly technology, since it is free from CFCs, HCFCs (i.e., refrigerants). Therefore, the DAC contributes zero global warming (GW) and ozone depletion (OD). Additionally, the desiccant material used in the DAC system could easily be regenerated using low-grade waste heat or solar thermal heating source. In addition, via the desiccant dehumidification AC method, up to $5 \%$ and $30 \%$ energy consumption for heating and cooling, respectively, can be reduced by using the DAC systems as compared to the VCAC systems [3]. The general DAC applications include buildings, agriculture product storage, greenhouse AC, livestock AC [4,7,45-49] supermarkets, schools, cold warehouses, ice arenas, theaters, hotels, hospitals, automobiles [50], wet markets [51], drying grains [52], marine ships $[53,54]$, and museums $[55,56]$. M-cycle supported DAC combines the characteristics of DAC and MAC. The M-DAC system attains two loads simultaneously. Latent load through the desiccant dehumidification process and sensible load through evaporative cooling [57-59]. M-DAC system is getting interested by the researchers and has been investigated in literature for humid climate [60-63].

In this research, a lab-scale open-cycle solid-silica-gel-based DAC experimental apparatus is locally developed. In literature, the DAC system comprises of desiccant blocks, rotor, or wheel that have a honeycomb like structure was used [4,64-67]. The significance of this research is that a solid-silica-gel-based DAC system was developed, at lab-scale, for the performance evaluation of the DAC system. In addition, this study offers researchers the opportunity to create their own solid-desiccant-based DAC systems at the lab-scale. According to Köppen-Giger climate classification, Multan has a warm desert climate. Concerning the climatic condition of Multan (Pakistan), the experimental data were obtained and analyzed. The experimental data were collected to evaluate the DAC system performance for such climatic conditions. The study proposed two kinds of systems: (i) standalone DAC system and (ii) M-cycle assisted DAC system. In addition, two kinds of desiccant material (i.e., silica gel and hydrophilic polymeric sorbent) are thermodynamically investigated for both system types, using the experimental data. The performance of the abovementioned systems is compared, and the feasibility of the systems is investigated on monthly basis by comparing dehumidification capacity, cooling capacity, and thermal coefficient of performance (COP) of the system.

\section{Materials and Methods}

\subsection{Experimental Section}

An open-cycle lab-scale desiccant experiment system was set up. It contained a heater, fan, desiccant material, accessories, sieves, anemometer (BENETECH, GM816) with an accuracy of $\pm 1.5 \mathrm{~m} / \mathrm{s}$ 
(5\%) and range of $0.3-30 \mathrm{~m} / \mathrm{s}$, temperature sensor (UNI-T, UT330A) with an accuracy $\pm 2{ }^{\circ} \mathrm{C}(1.6 \%)$ and range $-40-80{ }^{\circ} \mathrm{C}$, relative humidity sensor (UNI-T, UT330A) with an accuracy of $\pm 5 \%(5 \%)$ and range of $0-100 \%$, and pressure sensor (UNI-T, UT330A) with an accuracy of $\pm 3 \mathrm{hpa}(0.8 \%)$ and range 750-1100 hPa, respectively. A significant part of the desiccant system is the array of sieves because the adsorbent (desiccant material) is placed on it. The sieves are contrived with polyacrylic material and mesh. A total of 18 sieves are used for the desiccant system and were kept on each other in the form of a rectangular block. Each sieve has a dimension of $250 \mathrm{~mm} \times 145 \mathrm{~mm} \times 3 \mathrm{~mm}$, and about $68 \mathrm{~g}$ of silica gel is placed over each sieve. The total silica gel used in this experiment was approximately $1.22 \mathrm{~kg}$. The pictorial representation of the experimental setup is shown in Figure 1a.
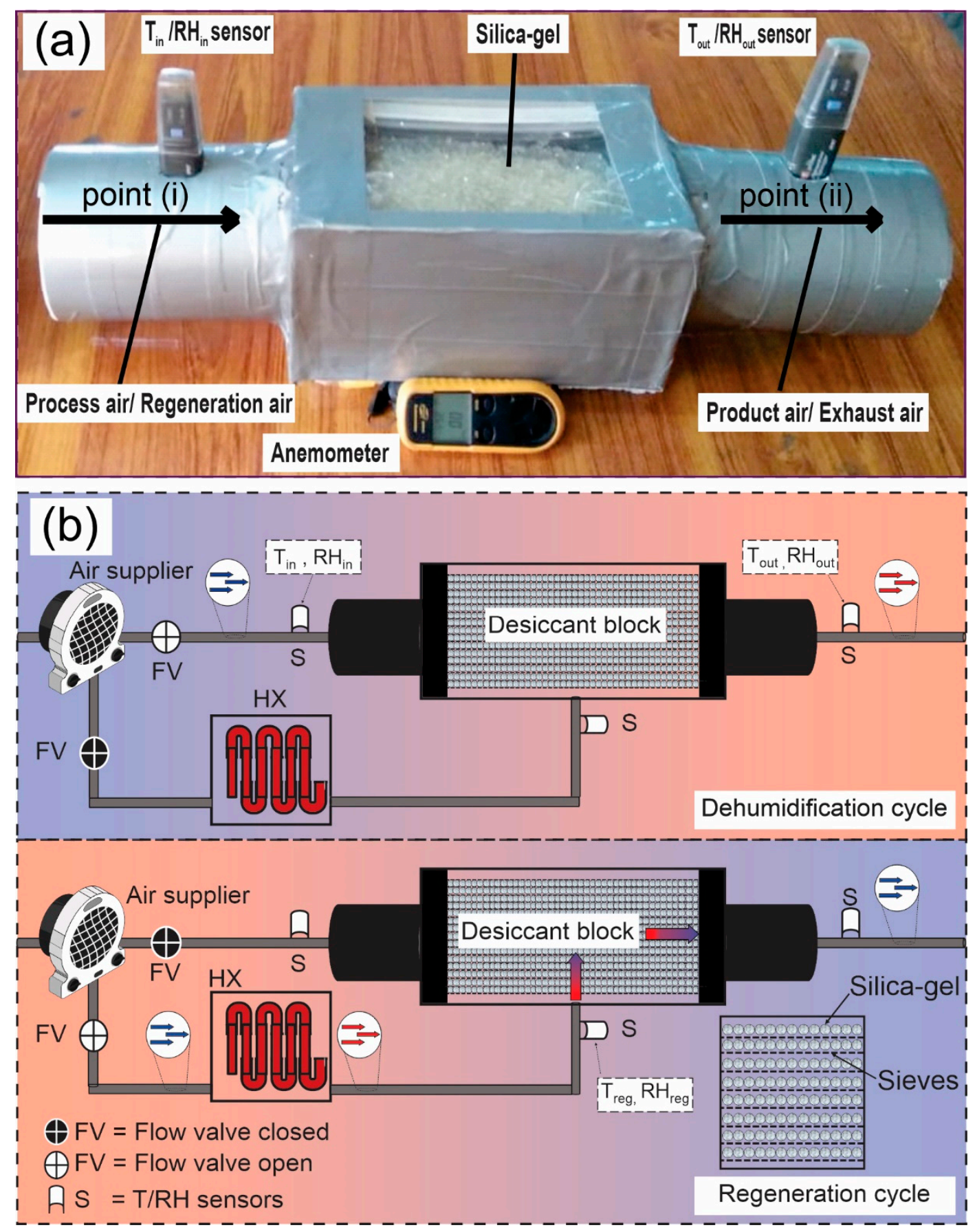

Figure 1. Pictorial representation of (a) the experimental system, and (b) schematic representation of the experimental system. 
As for as the experimental procedure is concerned, due to the high hydrophilic affinity of desiccant material (adsorbent) and pressure gradients between adsorbent and ambient air vapors adsorb on the adsorbent surface for a period. At the point where the surrounding air is crossed into the desiccant unit, due to the release of heat from adsorption, it becomes dry and relatively hot. After a while, the adsorbent of the desiccant system becomes saturated and its adsorption capacity reduces. Therefore, adsorbent must require its regeneration. This is achieved by passing the warm air over the desiccant system. The hot air clears the moisture away from the adsorbent surface and the material gets regenerated. The schematic diagram of the experimental setup is shown in Figure $1 \mathrm{~b}$. Therefore, the regeneration temperature for the regeneration of the adsorbent was set at $65-70{ }^{\circ} \mathrm{C}$. The mass flow rate of approximately 0.05 to $0.08 \mathrm{~kg} / \mathrm{s}$ was transferred via the desiccant system inlet and outlet.

\subsection{Data Processing}

The data on desiccant dehumidification were generated by the experimental apparatus for performance assessment of the DAC system. The dehumidification of ambient air takes place through the desiccant system and offers the outlet condition. The air conditions that passed through the heat exchanger (HX) and M-cycle cooling system are computed from Equations (1) and (2), respectively, given in the literature $[4,48]$. For completion of the cycle, the regeneration stream is provided to regenerate the desiccant. In the desiccant dehumidification process, the phase of water vapor changes from vapors to liquid and release equal heat of vaporization and condensation described as equivalent heat of adsorption. The equivalent heat of adsorption is calculated through Equation (6), and the total amount of water adsorption/desorption is determined by Equation (7) [68]. The enthalpy of the air is calculated by Equation (8) [69].

$$
\begin{gathered}
T_{3, d b}=T_{2, d b}-\varepsilon_{H X}\left(T_{2, d b}-T_{1, d b}\right) \\
T_{4, d b}=T_{3, d b}-\varepsilon_{w b}\left(T_{3, d b}-T_{1, w b}\right) \\
T_{6, d b}=T_{5, d b}-\varepsilon_{H X}\left(T_{2, d b}-T_{5, d b}\right) \\
X_{1}=X_{5}=X_{6}=X_{7} \\
X_{2}=X_{3}=X_{4} \\
q_{\text {eq }}=\dot{m}\left(h_{\text {out }}-h_{\text {in }}\right) \\
\Delta X=X_{\text {in }}-X_{\text {out }} \\
h=1.006 T_{d b}+X\left(2501+1.86 T_{d b}\right)
\end{gathered}
$$

where the subscripts (1-7) represent the air state conditions, as shown in Figure 2. $T_{d b}, \varepsilon_{H X}, \varepsilon_{w b}, T_{w b}, X$, $q_{\text {eq }}, \dot{m}, h_{\text {out }}, h_{\text {in }}, X_{\text {in }}$, and $X_{\text {out }}$ represent dry-bulb temperature $\left({ }^{\circ} \mathrm{C}\right)$, effectiveness of heat exchanger taken as 0.9 [4], wet-bulb effectiveness taken as 0.6 [4], wet-bulb temperature $\left({ }^{\circ} \mathrm{C}\right)$, humidity ratio $(\mathrm{g} / \mathrm{kg}$-DA), equivalent heat of adsorption (W), mass flow rate of air $(\mathrm{kg} / \mathrm{s})$, air enthalpy at outlet side of desiccant system $(\mathrm{kJ} / \mathrm{kg})$, air enthalpy at inlet side of desiccant system $(\mathrm{kJ} / \mathrm{kg})$, humidity ratio at outlet side of desiccant system (g/kg-DA), and humidity ratio at inlet side of desiccant system (g/kg-DA), respectively.

Ideally, for the duration of the dehumidification process, the dehumidification line slope on the psychrometric chart pursues an isenthalpic behavior. This means that the adsorption process is the same as the heat of water vapor condensation after the vapor stage to the liquid stage for the duration of the desiccant dehumidification. Although, via experimental results, it is concluded that the net adsorption heat is to some extent more than the ideal adsorption heat caused by the isosteric heat of adsorption [3,70]. The relationship between this behavior can be specified by Equation (9) [45]. The disparity among the actual slope of a line and ideal slope line on the psychrometric chart is mainly due to the kind of adsorption mechanism and adsorbent pair interactions. Consequently, it is intricate 
to stimulate the performance of desiccant precisely. As a result, the dehumidification line slope is experimentally developed, and several scenarios are explored to create a unique relationship for the desiccant dehumidification process. Equation (10) [68] specifies the slope of the actual or experimental dehumidification line. In addition, the cooling capacity, thermal COP of the standalone, M-cycle assisted DAC system and the amount of heat required to regenerate the desiccant are computed from Equations (11)-(14), respectively [6].

$$
\begin{gathered}
\phi^{*}=\frac{\Delta}{Q_{s t}} \phi_{h} \\
\phi^{*}=\frac{X_{\text {in }}-X_{\text {out }}}{T_{d b, \text { out }}-T_{d b, i n}} \\
Q_{c}=h_{1}-h_{4} \\
C O P=\frac{\dot{m}_{P A}}{\dot{m}_{R A}}\left(\frac{\text { Cooling capacity }}{\text { Heat input }}\right)=\frac{\left(h_{1}-h_{3}\right)}{\left(h_{6}-h_{5}\right)} \\
\text { COP }=\frac{\dot{m}_{P A}}{\dot{m}_{R A}}\left(\frac{\text { Cooling capacity }}{\text { Heat input }}\right)=\frac{\left(h_{1}-h_{4}\right)}{\left(h_{7}-h_{6}\right)} \\
Q_{\text {inp }}=m_{R A} C_{p}\left(T_{7}-T_{6}\right)
\end{gathered}
$$

where the subscripts $1,3,4,6$, and 7 represent the air state conditions, as shown in Figure 2. $\phi^{*}, \Delta, Q_{\text {st }}$ $\phi_{h}, X_{i n}, X_{o u t}, T_{d b, o u t}, T_{d b, \text { in }}, Q_{c}, C O P, \dot{m}_{P A}, \dot{m}_{R A}, Q_{i n p}$, and $C_{p}$ represent the slope of dehumidification line on psychrometric chart (-), heat of water vapor condensation $(\mathrm{kJ} / \mathrm{kg})$, isosteric heat of water vapor adsorption $(\mathrm{kJ} / \mathrm{kg})$, slope of enthalpy line on the psychrometric chart (-), humidity ratio at outlet side of desiccant system (g/kg-DA), humidity ratio at inlet side of desiccant system (g/kg-DA), dry-bulb temperature at outlet side of desiccant system $\left({ }^{\circ} \mathrm{C}\right)$, dry-bulb temperature at inlet side of desiccant system $\left({ }^{\circ} \mathrm{C}\right)$, cooling capacity $(\mathrm{kJ} / \mathrm{kg})$, coefficient of performance of the system $(-)$, mass flow rate of process air $(\mathrm{kg} / \mathrm{s})$, mass flow rate of regeneration air $(\mathrm{kg} / \mathrm{s})$, heat input required for regeneration of desiccant block $(\mathrm{kW})$, and specific heat capacity of air taken as $1.006(\mathrm{~kJ} / \mathrm{kg}-\mathrm{K})$, respectively.

Uncertainty in the data can arise from multiple sources, including imprecise measurement from the sensor, design limitations, human error, inaccurate procedure, and other important factors. The uncertainty analysis is necessary because the magnitude of the model needs to be contemplated when interpreting the results of the model calculations. Uncertainty analysis is carried out to measure the uncertainty in calculating the variables (temperature, relative humidity, pressure, and air velocity) at the time of the experiment. In desiccant data, the uncertainty is resolved by the root of the sum of squares method by Equation (15) [71,72]. The total uncertainties $\left(\sigma_{t}\right)$ during the measurement of air temperature, relative humidity and pressure is computed by Equation (16), as cited in the literature $[73,74]$.

$$
\begin{gathered}
\sigma_{R}=\sqrt{\left(\frac{\partial R}{\partial N_{1}} \alpha_{1}\right)^{2}+\left(\frac{\partial R}{\partial N_{2}} \alpha_{2}\right)^{2}+\ldots+\left(\frac{\partial R}{\partial N_{n}} \alpha_{N}\right)^{2}} \\
\sigma_{t}=\sqrt{\sigma_{\text {sen }}^{2}+\sigma_{\text {calibr }}^{2}+\sigma_{d a q}^{2}}
\end{gathered}
$$

where $\sigma_{R}, \alpha_{1}-\alpha_{N}, \mathrm{R}, N 1-N_{n}, \sigma_{t}, \sigma_{s e n} . \sigma_{c a l i b r}$, and $\sigma_{d a q}$ represent the total uncertainty in measuring the adsorption uptake, uncertainty in measuring different variables, a given function of independent variables, independent variables, total uncertainty in the measurement of temperature, relative humidity, and pressure (\%), uncertainties of a sensor, uncertainty in calibration, and uncertainty associated with data-acquisition system, respectively. The uncertainties in sensor, calibration, and data acquisition are provided by the manufacturer. Therefore, the measurement uncertainties in temperature, relative humidity, pressure drop, and velocity are $\pm 2.6, \pm 5.1, \pm 1.6$, and $\pm 5.1 \%$, respectively. 


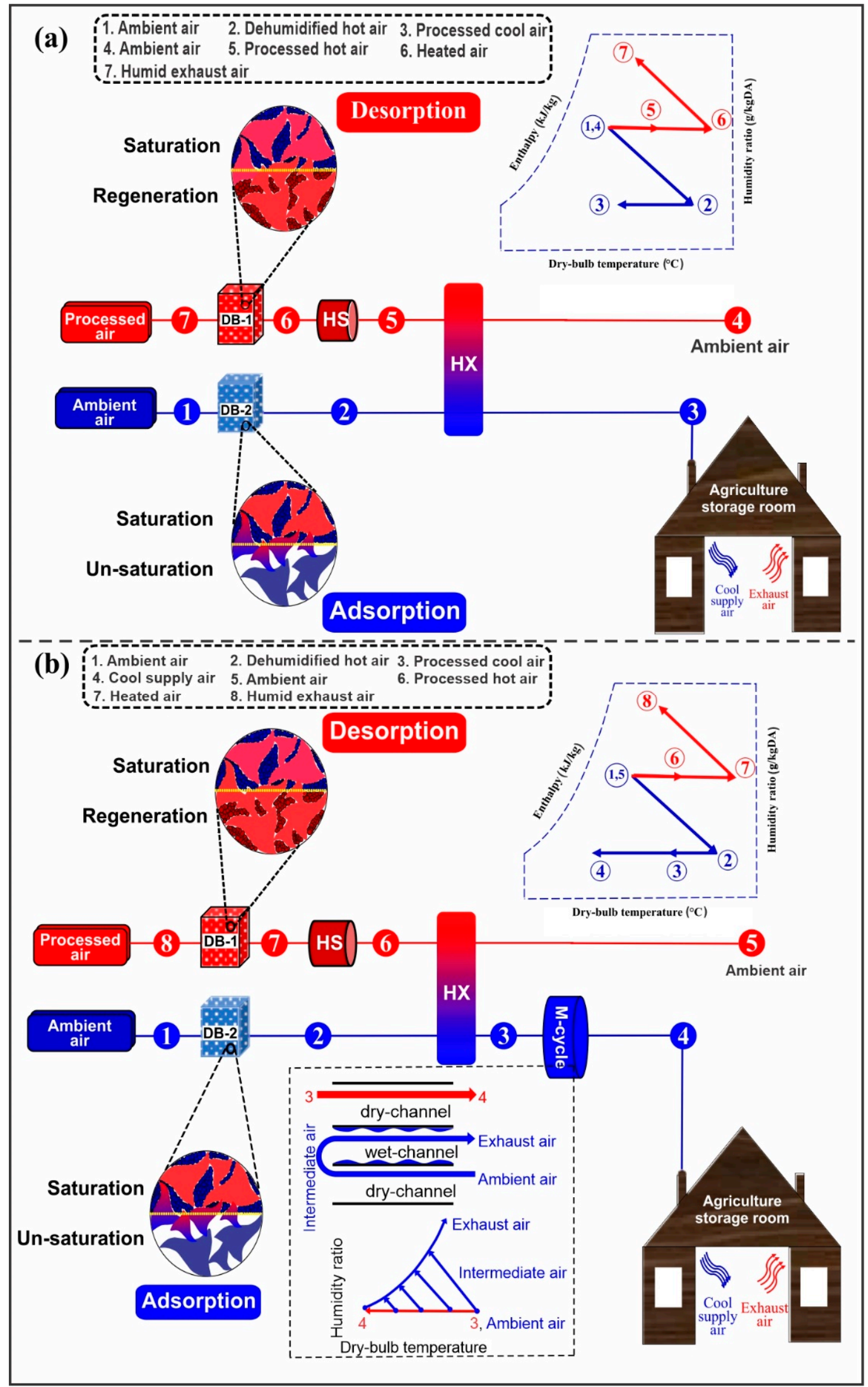

Figure 2. Schematic representation of (a) standalone desiccant air-conditioning (DAC) system and (b) Maisotsenko cycle (M-cycle)-based DAC system. 


\section{Proposed DAC System}

The current study concentrates on two types of AC systems that involve a (i) standalone DAC system and (ii) M-cycle assisted DAC system. In addition, two adsorbents (i.e., hydrophilic polymeric sorbent and silica gel) were investigated. In this research, the overall performance of proposed DAC systems was investigated, and the feasibility of such systems was explored for the climatic conditions of Multan (Pakistan). A concise depiction of these systems is provided below.

\subsection{Standalone DAC System}

Standalone DAC system contains a dehumidification unit coupled with a sensible heat exchanger (HX) and heating unit. There is no M-cycle cooling device that is solely use for the dehumidification of air. In Figure 2a, a schematic representation of the standalone DAC system is provided. The DAC system is used for the dehumidification of the air and results in an increase in temperature near the regeneration temperature of the desiccant (i.e., conditions 1 and 2). Furthermore, the hot and dehumidified air passes through the sensible HX, which reduces the temperature of dehumidified air without affecting the humidity ratio near to the ambient air (i.e., condition 3). Consequently, ambient air (i.e., condition 4) is used for the regeneration of desiccant block. The air passes through the heat exchanger as a return air which transfers the heat of process air into the regeneration air, slightly raising its temperature without affecting the humidity ratio (i.e., condition 5). The regeneration air passes through a low-grade heating source, which further increases the temperature of the regeneration air (i.e., condition 6). This hot and relatively dry regeneration air passes through the desiccant block which desorbs the adsorbate (water vapors, i.e., condition 7), hence completing the cycle. The psychrometric representation of conditions 1-7 are shown in Figure 2a.

\subsection{M-Cycle-Based DAC System}

A typical M-cycle assisted DAC system, as shown in Figure $2 b$, is intended for cooling and dehumidification of ambient air. The system consists of desiccant blocks with the inclusion of a flat plate heat exchanger, cooling device (M-cycle), and heat source for the regeneration of desiccant component. The DAC component is used to dehumidify the air, resulting in a rise in temperature near the desiccant's regeneration temperature (i.e., conditions 1 and 2). Moreover, the hot and dehumidified air passes through sensible HX, which decreases the dehumidified air close to the ambient air temperature without affecting the humidity ratio (i.e., condition 3 ). In addition, the cooled air passes through the M-cycle cooling device which further decreases the temperature without affecting the humidity ratio (i.e., condition 4). Consequently, ambient air (i.e., condition 5) is used for the regeneration of desiccant block. The air is passed through a heat exchanger as a return air which transfers the heat of process air into the regeneration air, slightly raising its temperature without affecting the humidity ratio (i.e., condition 6). The regeneration air passes through a low-grade heating source which further increases the temperature of the regeneration air (i.e., condition 7). This hot and relatively dry regeneration air passes through the desiccant block, which desorbs the adsorbate (water vapors, i.e., condition 8), hence completing the cycle. The regeneration temperature differs according to the type of adsorbent, ambient conditions, and many other factors. A parametric analysis was performed to analyze the parameters affecting the regeneration temperature $[3,75,76]$. The psychrometric representation of conditions 1-8 are shown in Figure $2 b$.

\section{Results and Discussion}

The desiccant dehumidification performance on an experimental basis was inspected for different processes and regeneration air conditions. Figure 3 shows the experimental profile of ambient air conditions of Multan with desiccant dehumidification at a regeneration temperature of $70^{\circ} \mathrm{C}$. In Figure 3, the dynamic nature of the process and regeneration temperature of $70{ }^{\circ} \mathrm{C}$ is shown, indicating that, after $240 \mathrm{~min}$, ambient air entered the desiccant system on $\mathrm{RH} \sim 73-88 \%$ and departed 
by $\mathrm{RH} \sim 38-59 \%$. Figure 4 shows the impact on the amount of equivalent heat of adsorption at different regeneration temperatures. The $q_{e q}$ increases with the increase in regeneration temperature; however, with respect to the time, it is decreased at both regeneration temperature. The line on the value of zero equivalent heat of adsorption shows the isenthalpic dehumidification. In addition, the impact on adsorption heat with respect to the desiccant performance explored in the literature [4].

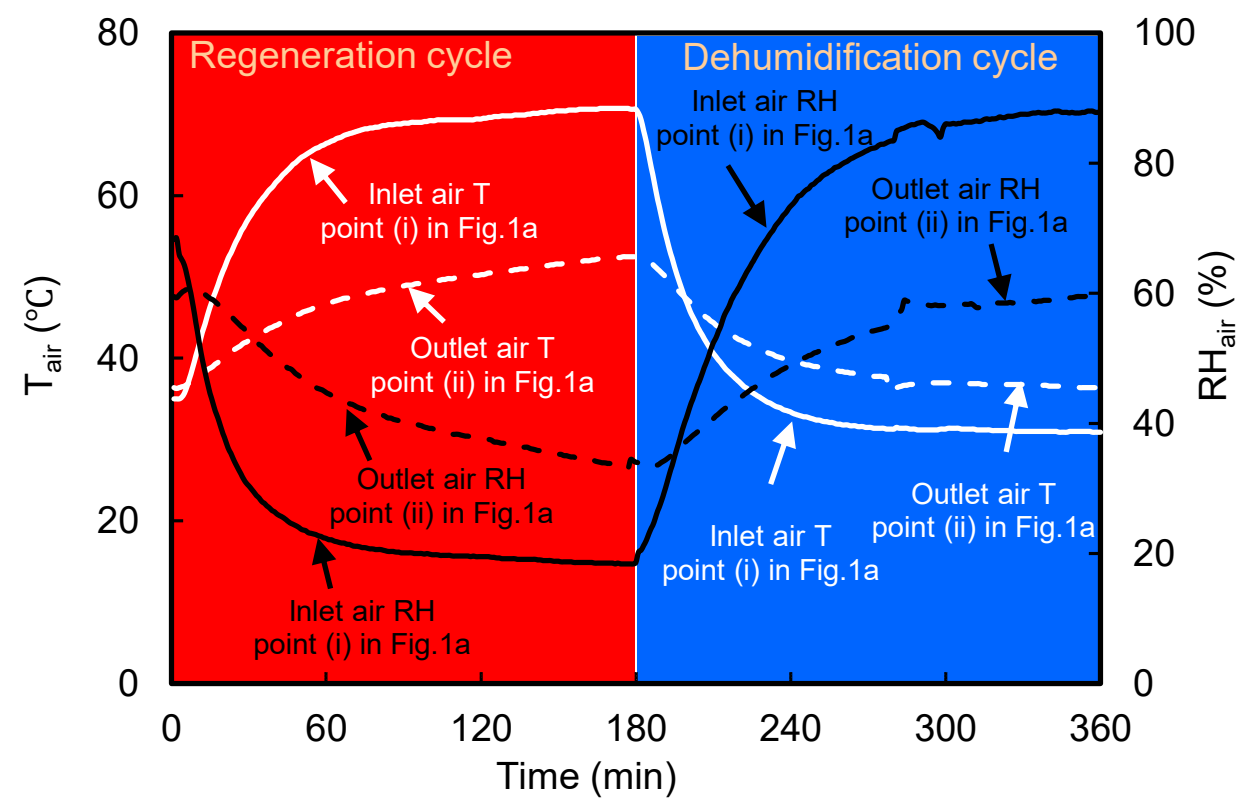

Figure 3. Regeneration and dehumidification cycle profiles of the DAC system at $70{ }^{\circ} \mathrm{C}$ regeneration temperature.

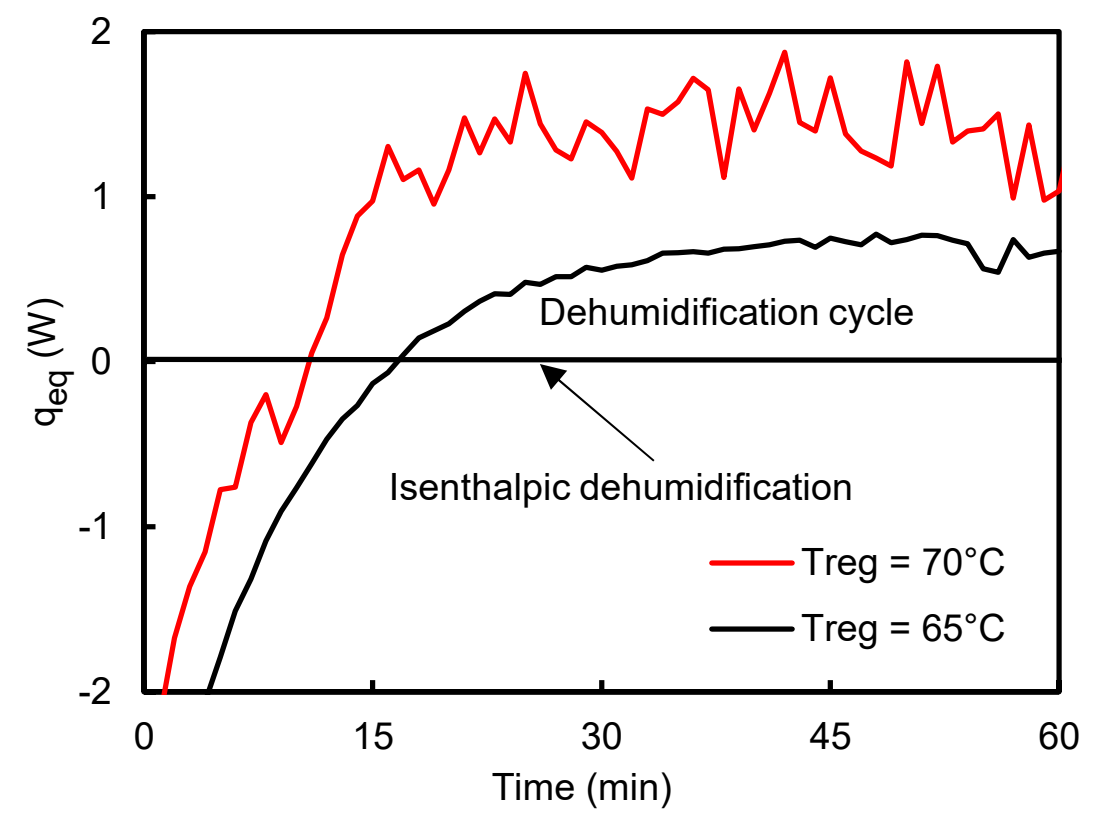

Figure 4. Impact on the amount of equivalent heat of adsorption at different regeneration temperatures.

Figure 5 shows that the amount of adsorption of water vapor increases with the regeneration temperature. As reported by thermodynamic laws, total water adsorption equals to the total water desorption at a certain regeneration temperature. The dehumidification cycle equals to the regeneration cycle at a certain regeneration temperature. The thermal COP of the desiccant system at different regeneration temperature is also compared for the condition of $\mathrm{T}_{\text {in }} \approx 37^{\circ} \mathrm{C}, \mathrm{X}_{\mathrm{in}} \approx 25 \mathrm{~g} / \mathrm{kg}$-DA by 
using $\varepsilon_{w b}=0.6$ and $\varepsilon_{H X}=0.9$. Figure 6a shows the system thermal COP at different regeneration temperature. Later the analysis was made with wet-bulb effectiveness utilized ranges from 0.6 to 1.3 to see the effect of changing the effectiveness of wet bulb on the system's thermal COP at different regeneration temperatures. Figure $6 \mathrm{~b}$ shows the influence of changing the effectiveness of wet bulb on the thermal COP of the desiccant system.

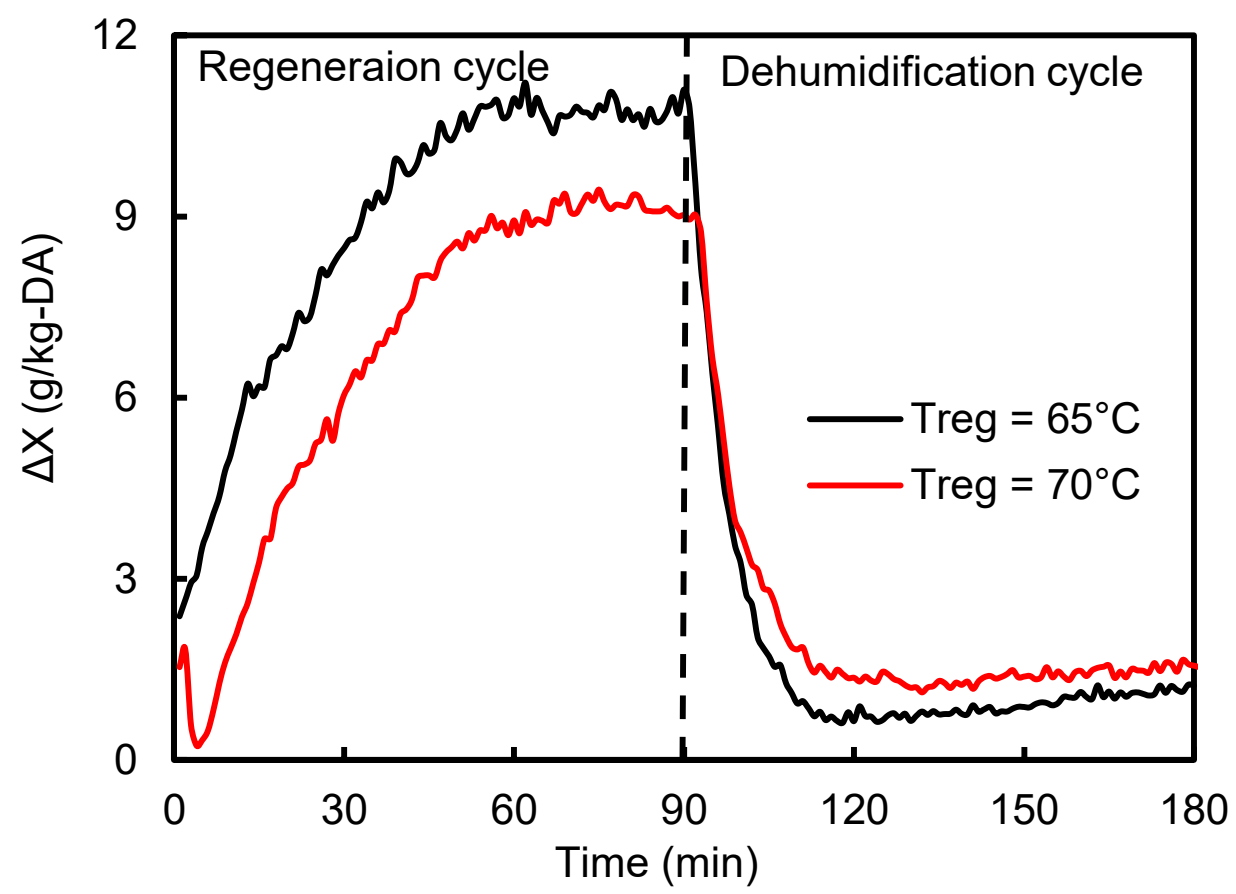

Figure 5. Impact of regeneration temperature on net dehumidification, for regeneration and dehumidification cycle of the DAC system.

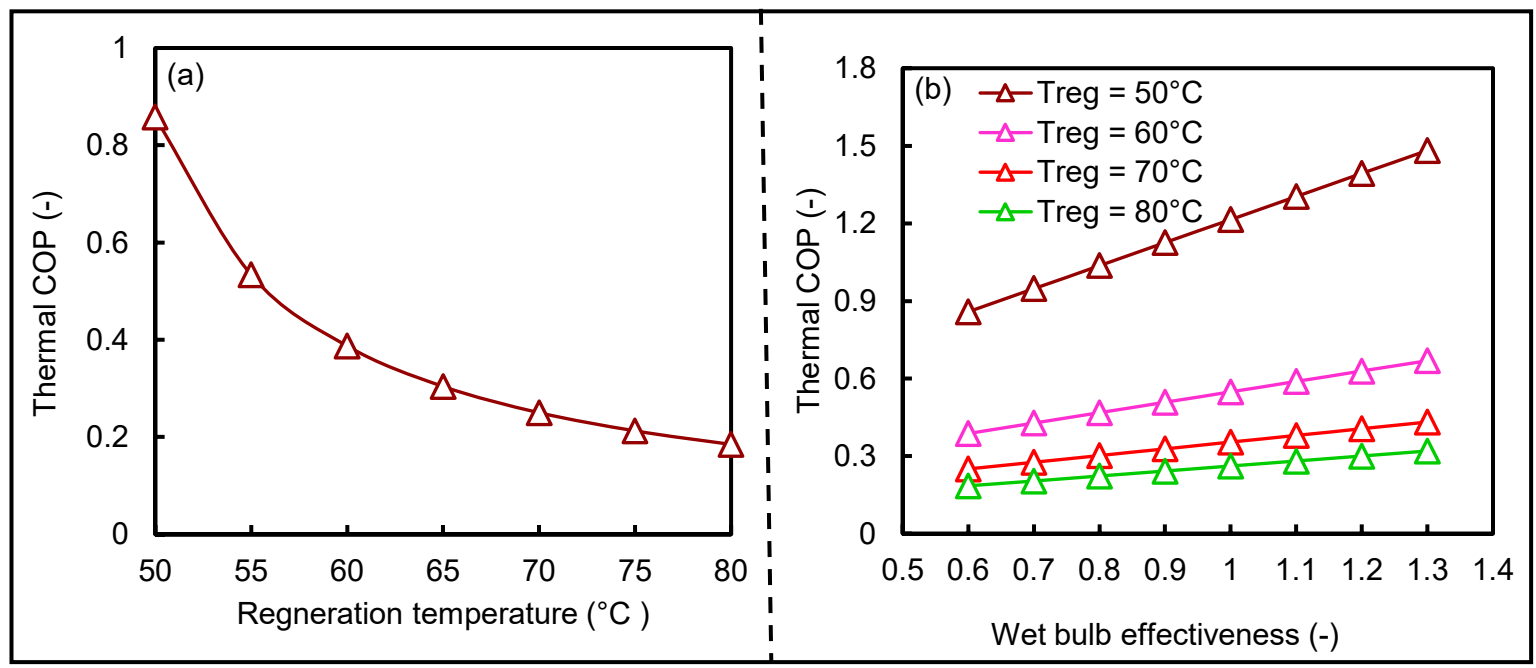

Figure 6. Comparison of thermal coefficient of performance (COP) at (a) wet-bulb effectiveness $=0.6$; and (b) different wet-bulb effectiveness against different regeneration temperatures.

Figure 7 shows the experimental evaluation of the slope of the dehumidification line at different regeneration temperatures. In Figure 7 , the $\phi^{*}$ does not fluctuate considerably for the $3600 \mathrm{~s}$. Therefore, the experimental value of the $\phi^{*}$ is utilized for simulating the desiccant dehumidification process. 


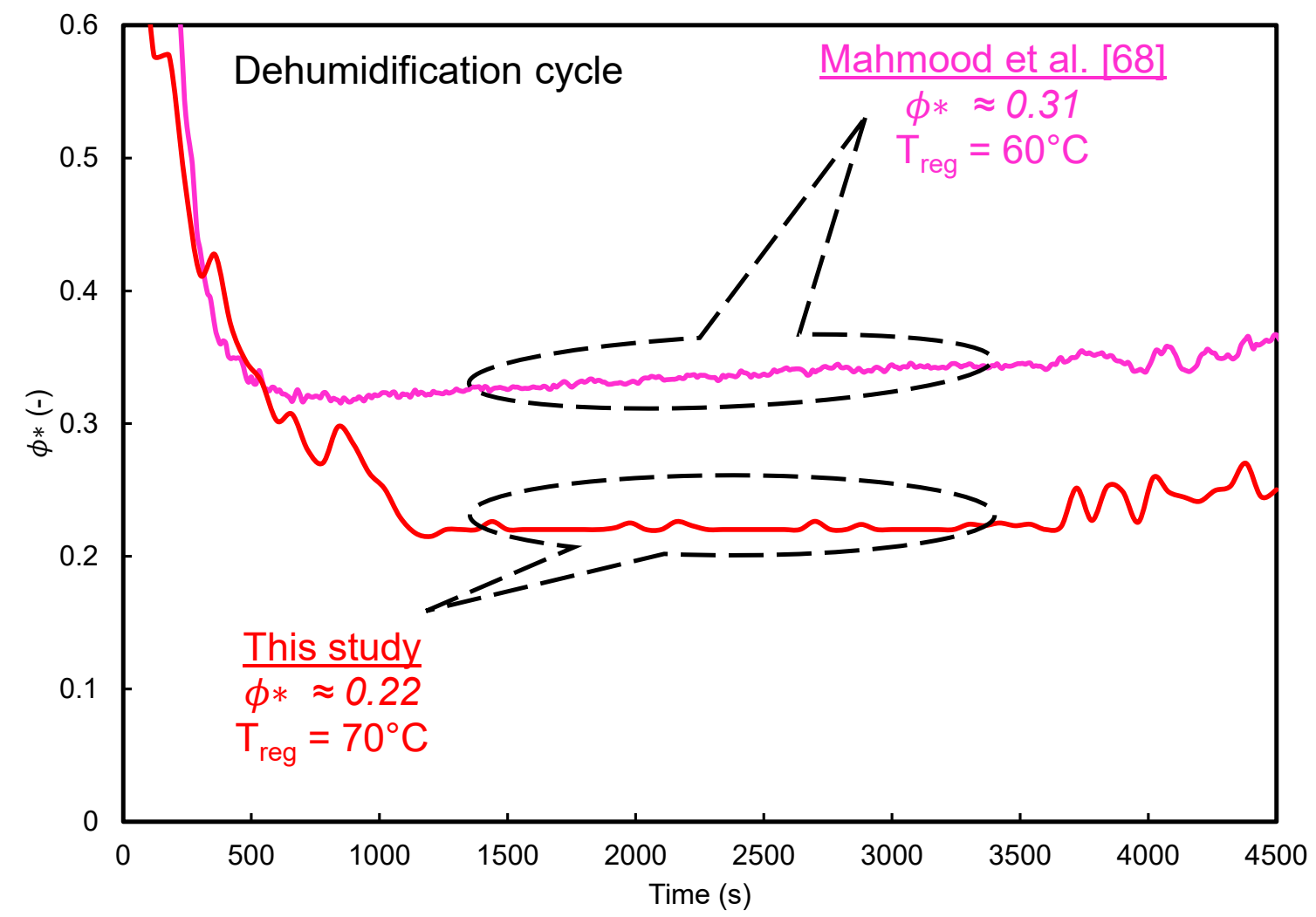

Figure 7. Experimental evaluation of the slope of the dehumidification line at different regeneration temperatures.

The slope $\phi^{*}=0.22$ has been utilized to stimulate the performance of standalone silica-gel-based DAC and silica-gel-based M-DAC systems. Likewise, hydrophilic polymer sorbent-based standalone DAC and hydrophilic-polymer-based M-DAC desiccant systems performance are also related using $\phi^{*}=0.31$ [68]. The simulation has been applied on an hourly (13 July), daily, and monthly basis for the climatic condition of Multan (Pakistan) by 20-year average data occupied from Meteonorm software, to evaluate the dynamic performance of proposed DAC systems. Figure 8 shows the thermodynamic performance of (a) silica-gel-based standalone DAC system and (b) standalone polymer-based DAC system on an hourly, daily, and monthly basis for the climatic conditions of Multan. Figure 8a,b show that inlet ambient air temperature varies from $28.3^{\circ} \mathrm{C}(1: 00$ a.m. $)$ and progressively increases to $37^{\circ} \mathrm{C}$ (3:00 p.m.) and then decreases to $28^{\circ} \mathrm{C}$ (12:00 a.m.), at the same time inlet relative humidity, frequently shifting from $51 \%$ to the maximum value of $97 \%$ during the whole day. Furthermore, the change in temperature and relative humidity after dehumidification varies from 45 to $48{ }^{\circ} \mathrm{C}, 21 \%$ to $29 \%$, and 43 to $46{ }^{\circ} \mathrm{C}$, for silica-gel-based and polymer-based DAC system, respectively. The daily inlet ambient temperature and relative humidity vary from 27 to $38^{\circ} \mathrm{C}$ and from $56 \%$ to $93 \%$, respectively, throughout the month. The change in relative humidity and temperature after dehumidification ranges from $19 \%$ to $35 \%, 45$ to $48{ }^{\circ} \mathrm{C}$, and 43 to $45.5^{\circ} \mathrm{C}$, in both silica-gel-based and polymer-based DAC systems, respectively. Likewise, monthly temperature and relative humidity variation are displayed for both silica- and polymer-based DAC systems. 


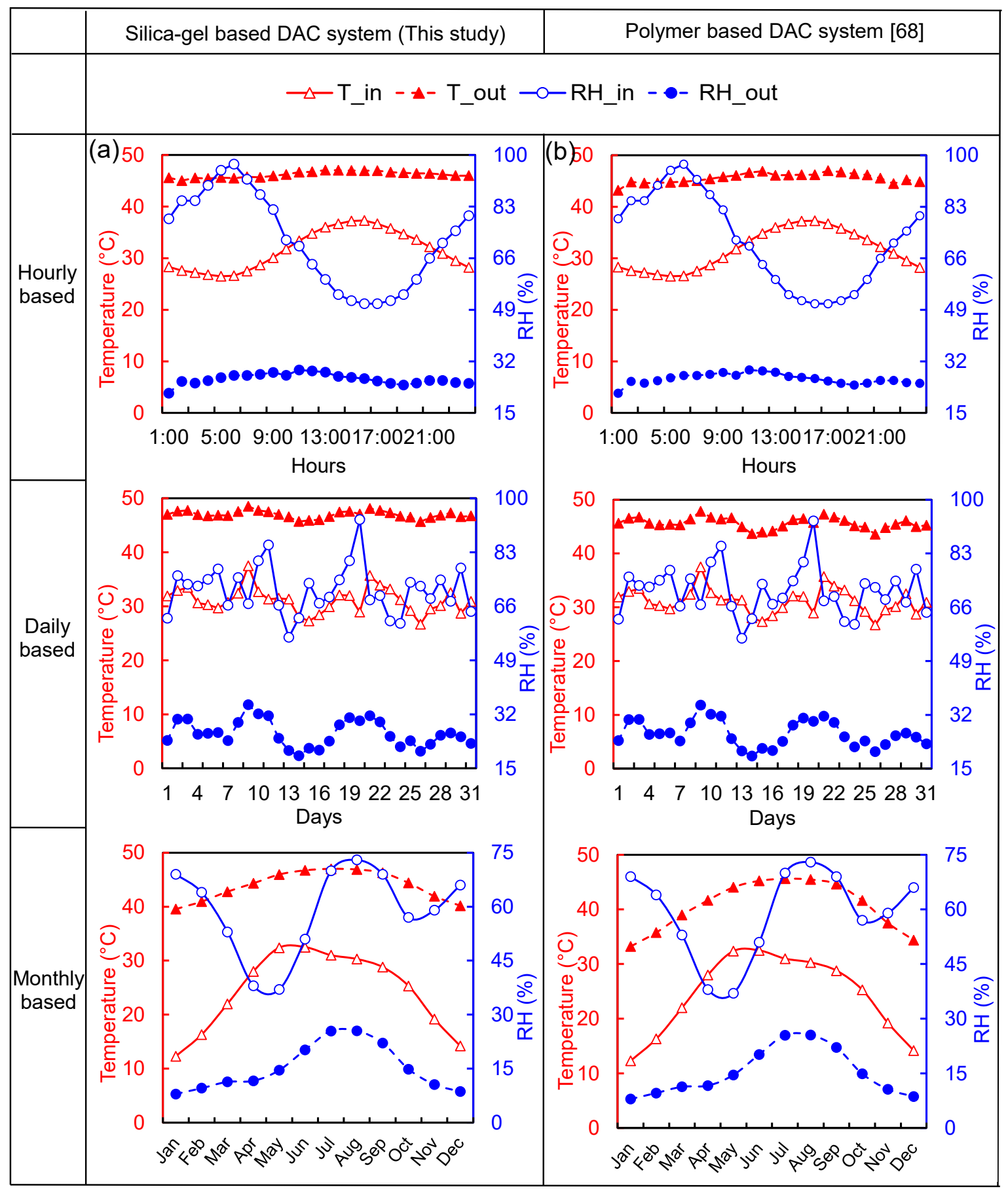

Figure 8. Thermodynamic performance of (a) silica-based standalone DAC system, and (b) polymer-based DAC system on an hourly, daily, and monthly basis for the climatic condition of Multan (Pakistan).

Figure 9 shows the thermodynamic performance of (a) silica-gel-based DAC system coupled with M-cycle cooling system, and (b) polymer-based DAC system coupled with M-cycle cooling system on an hourly, daily, and monthly basis, for the climatic conditions of Multan. In Figure 9, hourly temperature ranging from 22 to $28{ }^{\circ} \mathrm{C}$, at a relative humidity of $80-88 \%$ for silica-gel-based M-DAC system, and temperature ranging from 22 and $27^{\circ} \mathrm{C}$, at a relative humidity of $69-84 \%$ for polymer-based M-DAC system. Figure 9 shows daily temperature ranging from 21 to $31{ }^{\circ} \mathrm{C}$, at a relative humidity of 76-93\% for silica-gel-based M-DAC system, and temperature ranging from 21 to $30{ }^{\circ} \mathrm{C}$, at a relative humidity of $71-90 \%$ for polymer-based M-DAC system. Similarly, profiles of 
monthly temperature and relative humidity for silica-gel-based and polymer-based M-DAC systems are also shown in Figure 9. These results display that polymer-based M-DAC system provides more cooling and less relative humidity as compared to silica-based M-DAC system, which is better than the standalone DAC system for the climatic conditions of Multan, Pakistan, especially for July (i.e., heavy rainfall season, resulting in suffocation) $[77,78]$.

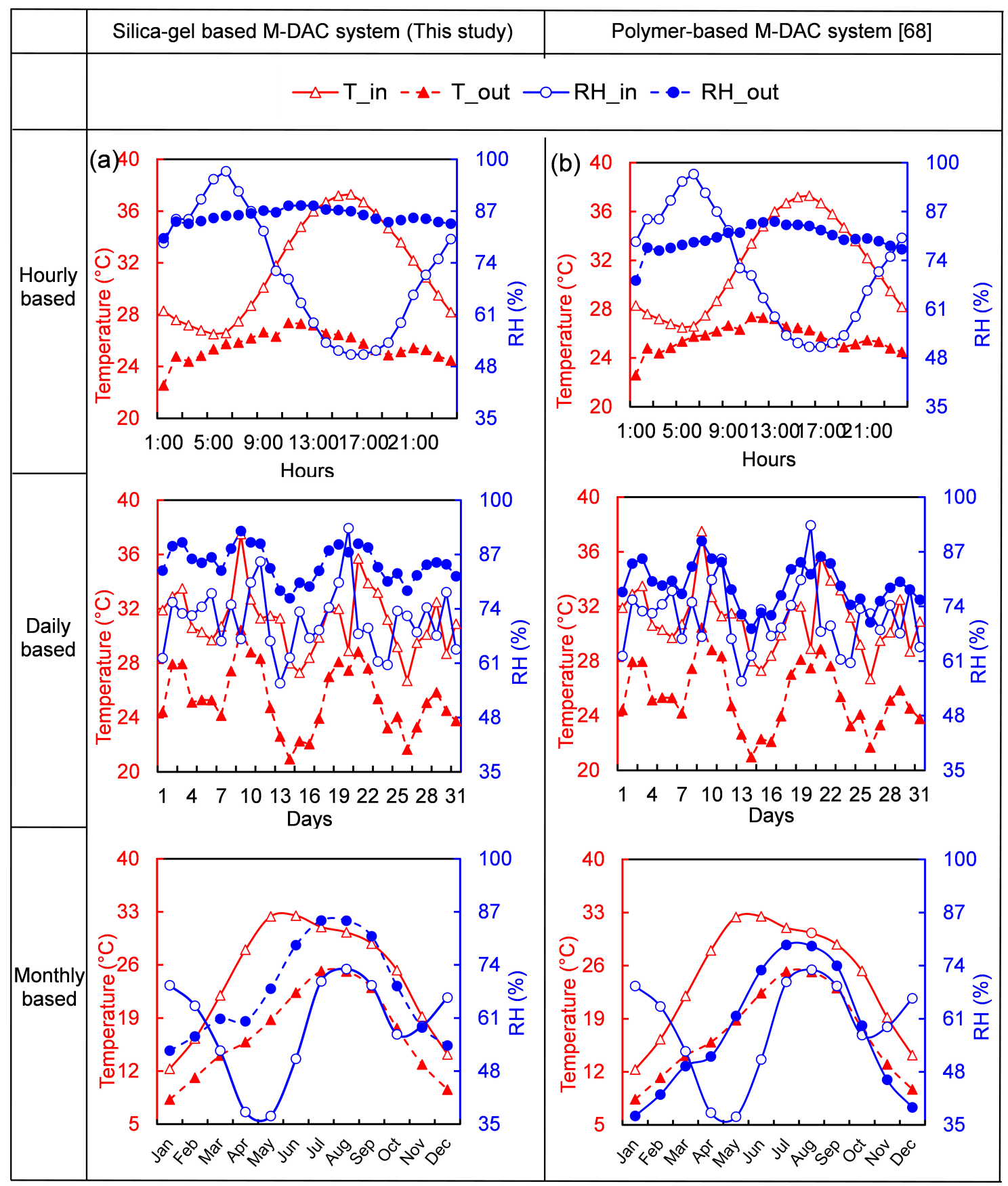

Figure 9. Thermodynamic performance of (a) silica-based DAC system with M-cycle unit, and (b) polymer-based DAC system with M-cycle unit on hourly, daily, and monthly basis for the climatic condition of Multan (Pakistan). 
Figure 10 shows the temperature and relative humidity profile of average year data for the climatic condition of Multan (Pakistan). Figure 11 shows the monthly performance of the investigated systems (i.e., standalone silica-gel-based, standalone polymer-based, M-cycle-based silica-gel-based, and M-cycle-based polymer-based DAC systems) on psychrometric chart plots.

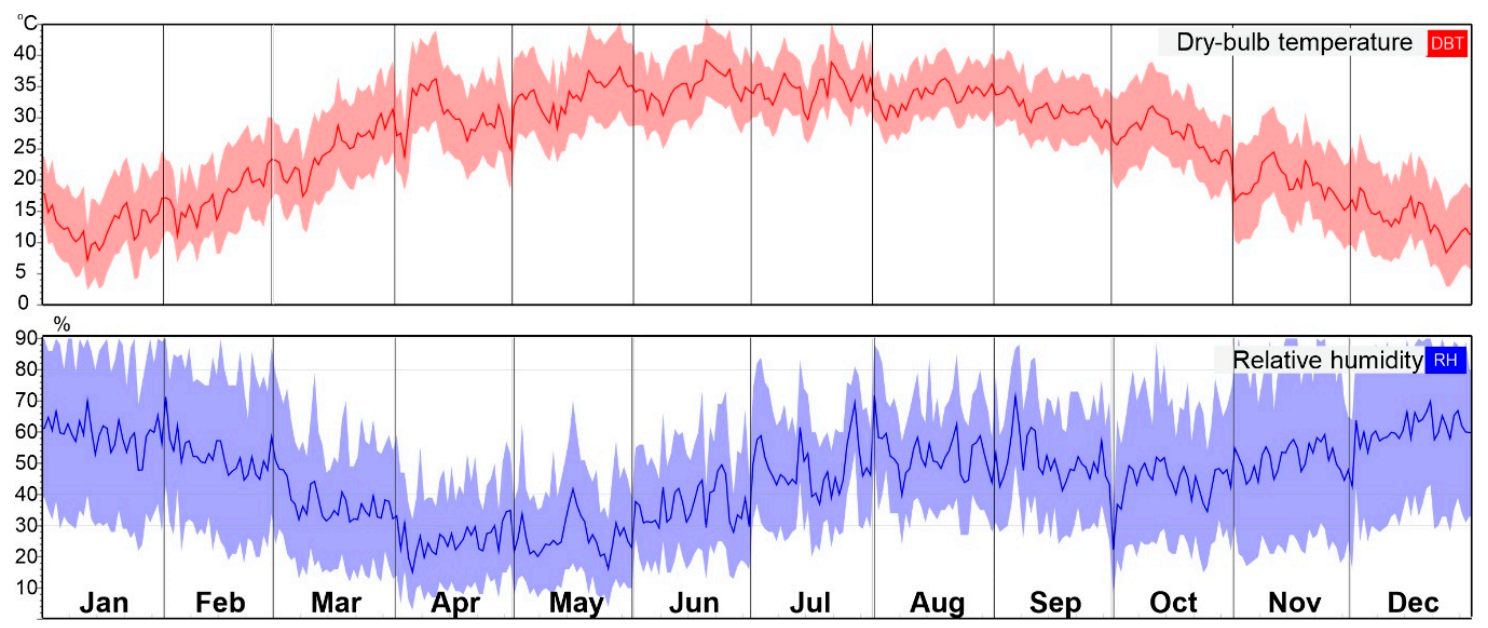

Figure 10. Temperature and relative humidity profile of test reference year for the climatic condition of Multan (Pakistan).

Figure 12a shows the monthly profile of the dehumidification capacity of silica-gel-based and polymer-based DAC system at $70{ }^{\circ} \mathrm{C}$ regeneration temperature for the climatic conditions of Multan (Pakistan). Moreover, the monthly profile of the dehumidification capacity of the polymer-based and silica-gel-based DAC systems at different regeneration temperatures are shown in Appendix A Figure A1. Results from Appendix A Figure A1 conclude that the desiccant dehumidification capacity increases with the increase in regeneration temperature. Figure $12 \mathrm{~b}$ shows the monthly profile of the cooling capacity of silica-gel-based and polymer-based M-DAC systems at a $70{ }^{\circ} \mathrm{C}$ regeneration temperature for the climatic conditions of Multan (Pakistan). In Figure 12b, the cooling capacity of the polymer-based M-DAC system is higher than the silica-gel-based M-DAC system. Moreover, the monthly profile of the cooling capacity of silica-gel-based and polymer-based M-DAC systems at different regeneration temperatures is shown in Appendix A Figure A2.

Figure 12c shows the monthly profile of heat input required for the regeneration of silica-gel-and polymer-based DAC system at $70^{\circ} \mathrm{C}$ regeneration temperature. According to Figure $12 \mathrm{c}$, the polymer-based DAC system requires more heat input for its regeneration throughout the year, as compared to the silica-gel-based DAC system at $70^{\circ} \mathrm{C}$ regeneration temperature. Additionally, the monthly profiles of the heat input required at different regeneration temperatures are given in Appendix A Figure A3. Figure $12 \mathrm{~d}$ shows the monthly profile of thermal COP of polymer-based and silica-gel-based standalone DAC and M-DAC systems. According to Figure $12 \mathrm{~d}$, the polymer-based standalone DAC and M-DAC system possess higher thermal COP (i.e., $0.24,0.47$ in May) at $70{ }^{\circ} \mathrm{C}$ regeneration temperature, as compared to the silica-gel-based M-DAC system (i.e., $0.21,0.36$ in May) respectively. Additionally, the monthly profiles of thermal COP of silica-gel-based and polymer-based M-DAC systems at different regeneration temperatures are given in Appendix A Figure A4. 


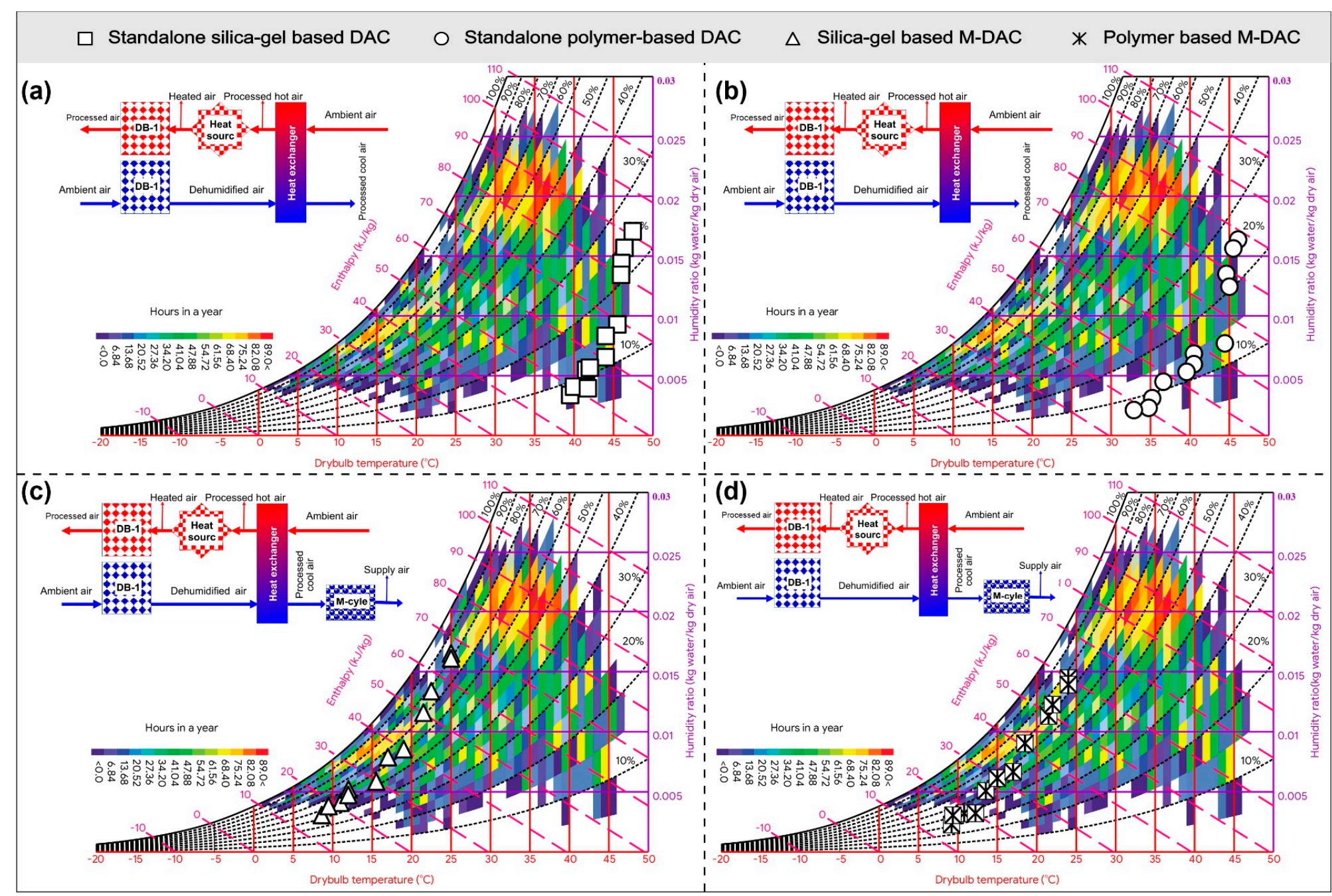

Figure 11. Psychrometric representation of monthly profile for (a) standalone silica-gel-based DAC system, (b) standalone polymer-based DAC system, (c) silica-gel-based M-DAC system, and (d) polymer-based M-DAC system. 

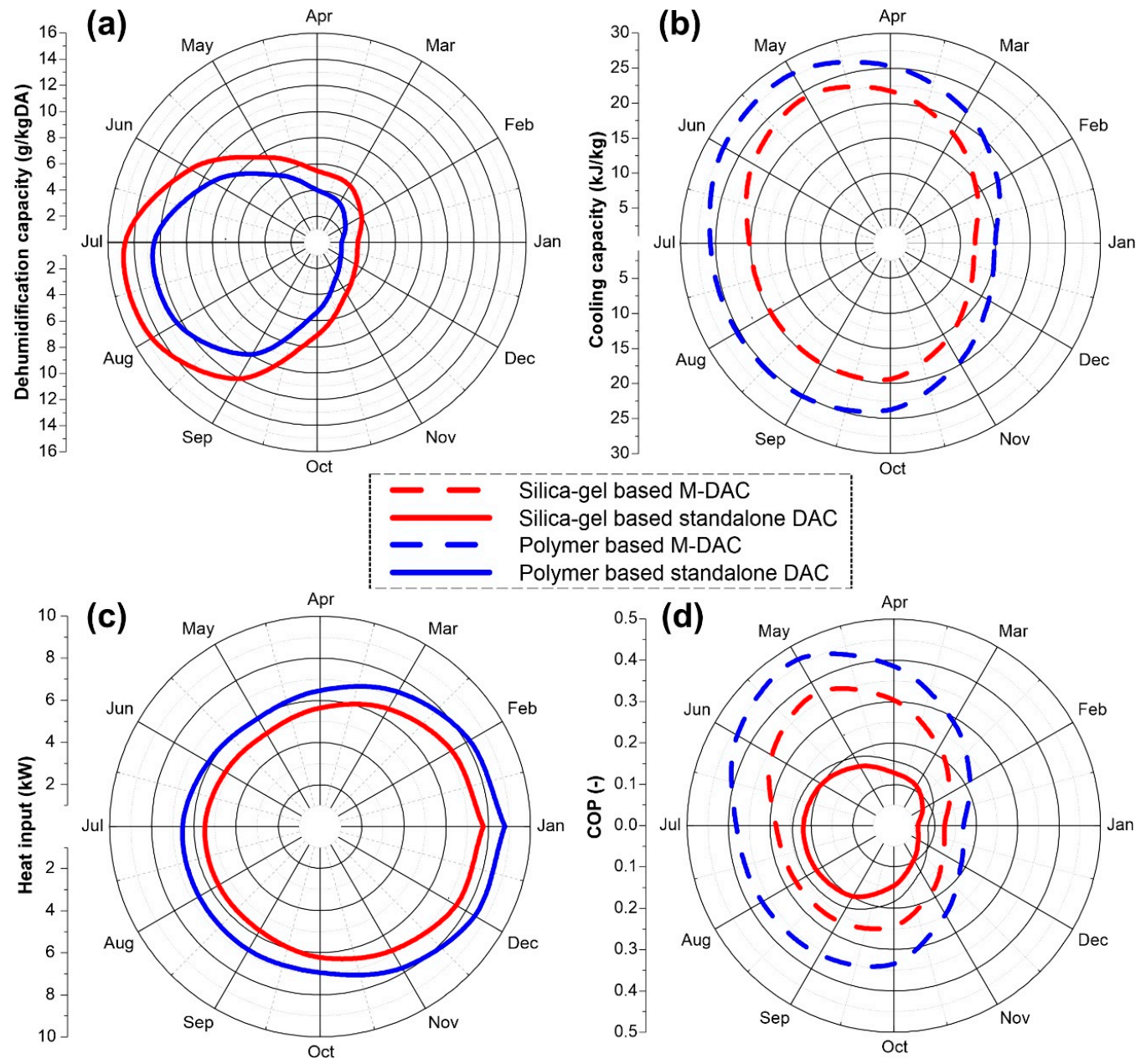

Figure 12. Monthly profile of (a) dehumidification capacity, (b) cooling capacity, (c) heat input, and (d) thermal COP for proposed AC systems.

\section{Conclusions}

In the present study, a lab-scale open cycle silica-gel-based experimental apparatus was set up for desiccant air-conditioning (DAC). The experiments were performed at the various process and regeneration air conditions for the climatic condition of Multan (Pakistan). Consequently, a steady-state analysis approach was used for the desiccant dehumidification process of the system. Thereby, the slope of the dehumidification line on the psychrometric chart was examined for identifying the actual desiccant dehumidification process based on experimental data which are found, $\phi^{*}=0.22$. This value is lower than the slope of the hydrophilic polymeric sorbent, $\phi^{*}=0.31$, available in the literature. This study proposed two kinds of AC systems that include the standalone DAC system and Maisotsenko-cycle-based DAC (M-DAC) system. In addition, two kinds of adsorbent (i.e., silica gel and hydrophilic polymeric sorbent) were thermodynamically investigated for both system types, using experimental data and associated results. The study aimed to explore the optimum AC system, as well as optimum adsorbent (desiccant) material for building AC application. The performance of proposed AC systems and adsorbent materials were investigated in perspectives of dehumidification capacity, cooling capacity, and thermal COP. The results showed that the hydrophilic-polymeric-based sorbent has a better performance, as compared to silica gel. The dehumidification capacity of hydrophilic polymeric sorbent (i.e., desiccant material) is greater than the silica gel at $70{ }^{\circ} \mathrm{C}$ regeneration temperature. In the case of proposed AC systems, the results show that the M-DAC system has a better performance, as compared to the standalone DAC system. Accordingly, the maximum thermal COP was obtained by a standalone DAC system (i.e., 0.36) and M-DAC system (i.e., 0.47) at a $70{ }^{\circ} \mathrm{C}$ regeneration temperature. 
Author Contributions: Conceptualization, M.A., G.H., and M.S.; data curation, M.A. and G.H.; formal analysis, M.A., G.H., M.S., M.H.M., and F.S.; funding acquisition, M.S. and T.M.; investigation, M.A., G.H., T.M., M.H.M., M.I.S., A.N., and F.S.; methodology, M.A., G.H., T.M., and M.H.M.; project administration, M.S.; resources, M.S.; software, M.A., G.H., M.H.M., and F.S.; supervision, M.S.; validation, M.S. and T.M.; visualization, T.M. and Z.M.K.; writing—original draft, M.A. and G.H.; writing—review and editing, M.S., T.M., M.I.S., A.N., and Z.M.K. All authors have read and agreed to the published version of the manuscript.

Funding: This research received no external funding.

Acknowledgments: This work is part of the Ph.D. research of Ghulam Hussain (second author). This research work was carried out in the Department of Agricultural Engineering, Bahauddin Zakariya University, Multan, Pakistan. This research was funded by Bahauddin Zakariya University, Multan, Pakistan, under the Director Research/ORIC grant entitled "Thermodynamic Evaluation of Low-Cost Air-Conditioning Systems for Various Applications", awarded to Principal Investigator Muhammad Sultan.

Conflicts of Interest: The authors declare no conflict of interest.

\section{Nomenclature}

\begin{tabular}{|c|c|}
\hline ACS & air-conditioning systems \\
\hline $\mathrm{AC}$ & air-conditioning \\
\hline COP & coefficient of performance \\
\hline$C_{p}$ & specific heat capacity of air $(\mathrm{kJ} / \mathrm{kg}-\mathrm{K})$ \\
\hline DAC & desiccant air-conditioning \\
\hline DEC & direct evaporative cooling \\
\hline EC & evaporative cooling \\
\hline GW & global warming \\
\hline h & enthalpy of air $(\mathrm{kJ} / \mathrm{kg})$ \\
\hline $\mathrm{HCFC}_{\mathrm{S}}$ & hydrochlorofluorocarbons \\
\hline $\mathrm{HFC}_{\mathrm{S}}$ & hydrofluorocarbons \\
\hline HVAC & heating, ventilation, and air-conditioning \\
\hline $\mathrm{HX}$ & heat exchanger \\
\hline IEC & indirect evaporative cooling \\
\hline MEC & Maisotsenko cycle evaporative cooling \\
\hline MAC & Maisotsenko cycle-based air-conditioning \\
\hline M-DAC & Maisotsenko cycle based desiccant air-conditioning \\
\hline M-IEC & Maisotsenko cycle-based indirect evaporative cooling \\
\hline$N 1-N_{n}$ & independent variables in measuring uncertainty \\
\hline OD & ozone depletion \\
\hline$Q_{c}$ & cooling capacity $(\mathrm{kJ} / \mathrm{kg})$ \\
\hline$q_{e q}$ & equivalent heat of adsorption (W) \\
\hline$Q_{\text {inp }}$ & heat required for regeneration of desiccant $(\mathrm{kW})$ \\
\hline$Q_{\text {st }}$ & isosteric heat of water vapor adsorption $(\mathrm{kJ} / \mathrm{kg})$ \\
\hline $\mathrm{RH}$ & relative humidity (\%) \\
\hline $\mathrm{T}$ & temperature $\left({ }^{\circ} \mathrm{C}\right)$ \\
\hline VCAC & vapor compression air-conditioning \\
\hline$X$ & humidity ratio (g/kg-DA) \\
\hline$\Delta X$ & difference in humidity ratio (in-out) (g/kg-DA) \\
\hline$\phi_{h}$ & slope of enthalpy line (-) \\
\hline$\phi^{*}$ & slope of dehumidification line (-) \\
\hline$\varepsilon$ & effectiveness (-) \\
\hline$\sigma$ & uncertainties (-) \\
\hline$\dot{m}$ & mass flow rate of air $(\mathrm{kg} / \mathrm{s})$ \\
\hline$\sigma_{R}$ & total uncertainty in adsorption uptake \\
\hline$\alpha_{1}-\alpha_{N}$ & uncertainty in measuring different variables \\
\hline$\sigma_{t}$ & total uncertainty $(\%)$ \\
\hline
\end{tabular}




$\begin{array}{ll}\text { Subscripts } & \\ \text { calibr } & \text { calibration } \\ \text { daq } & \text { data acquisition system } \\ \mathrm{db} & \text { dry bulb } \\ \text { in } & \text { inlet condition } \\ \text { out } & \text { outlet condition } \\ \text { PA } & \text { process air } \\ \text { RA } & \text { regeneration air } \\ \text { reg } & \text { regeneration } \\ \text { sen } & \text { sensor } \\ \text { wb } & \text { wet bulb }\end{array}$

\section{Appendix A}

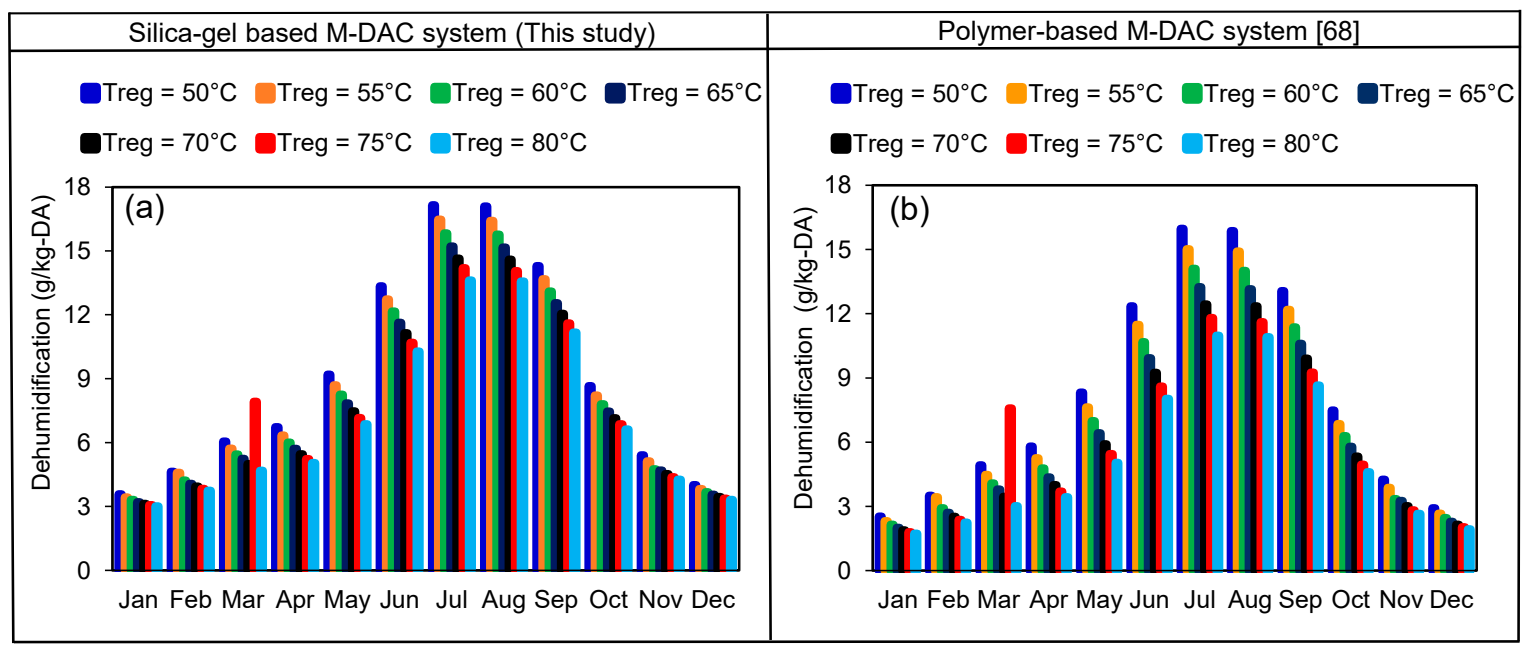

Figure A1. Dehumidification capacity of (a) silica-gel-based DAC system and (b) polymer-based DAC system at different regeneration temperatures.

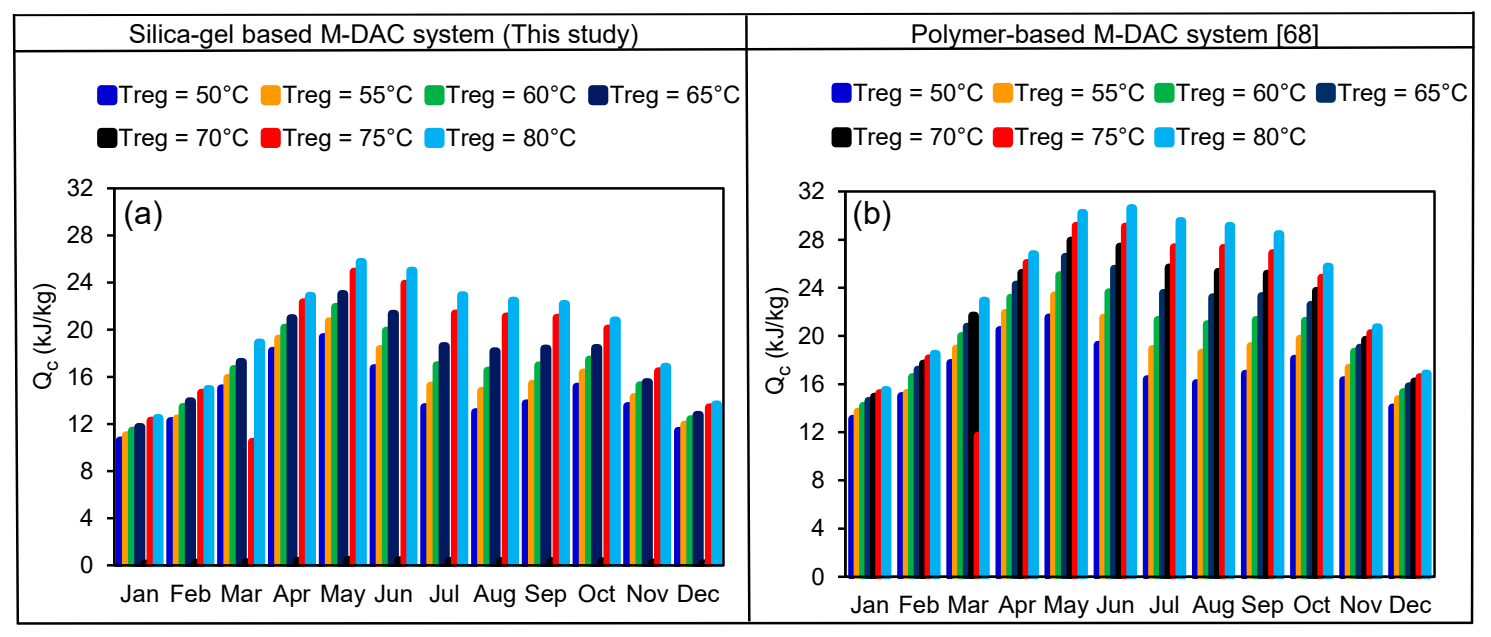

Figure A2. The cooling capacity of (a) silica-gel-based M-DAC system and (b) polymer-based M-DAC system at different regeneration temperatures. 


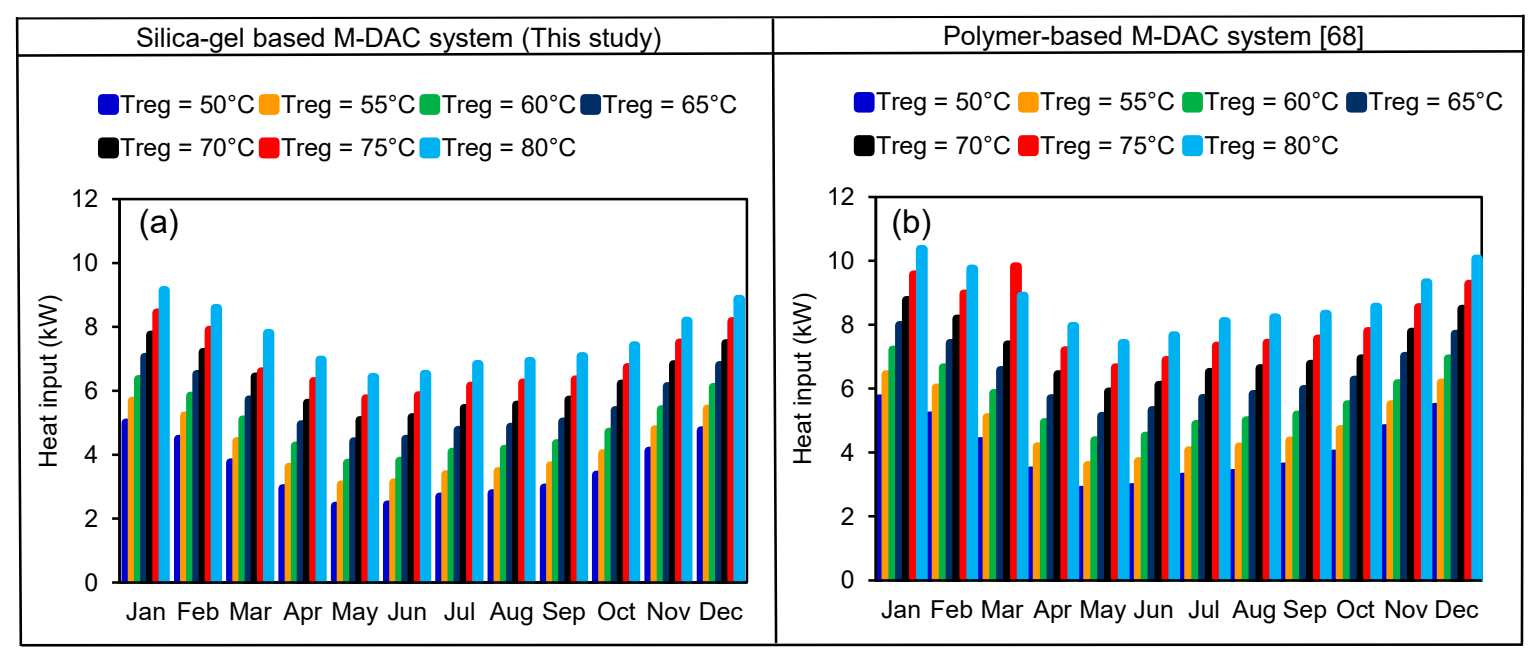

Figure A3. Heat input required for (a) silica-gel-based DAC system and (b) polymer-based DAC system at different regeneration temperatures.

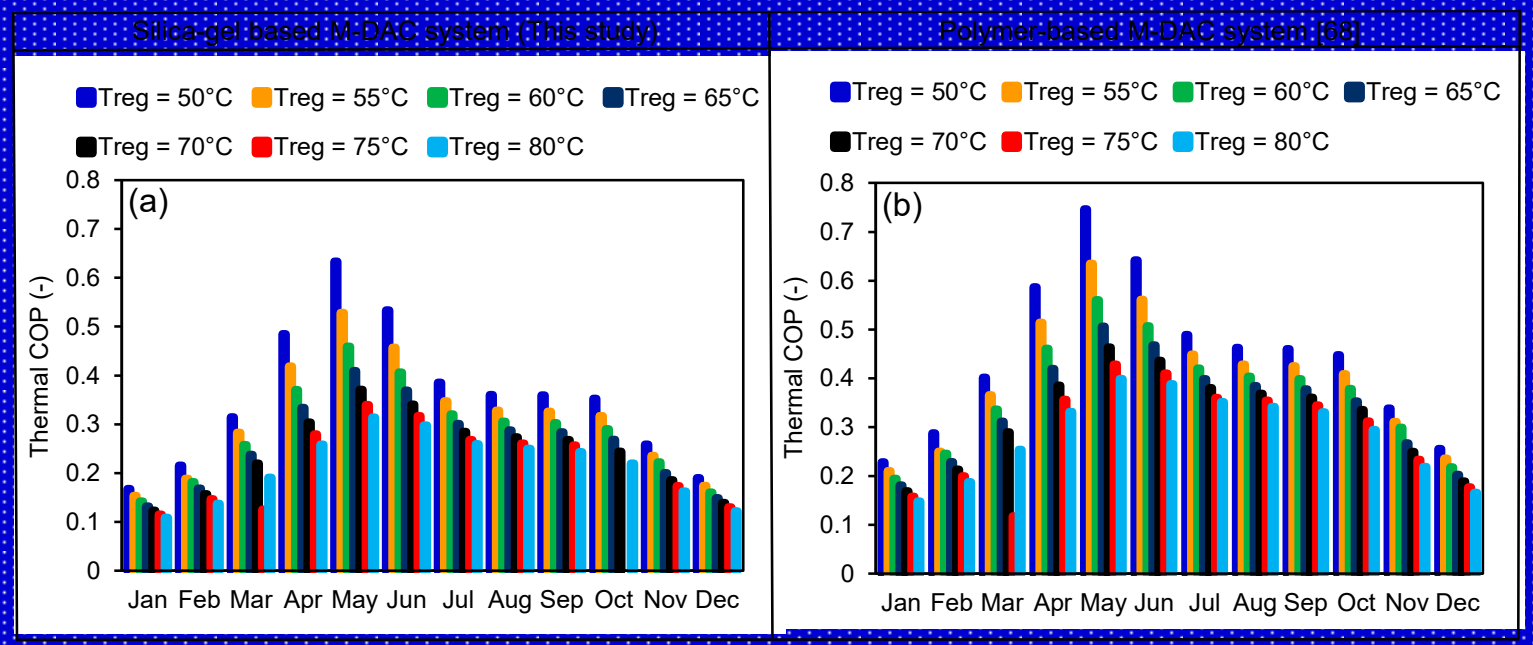

Figure A4. Thermal coefficient of performance of (a) silica-gel-based M-DAC system and (b) polymer-based M-DAC system at different regeneration temperatures.

\section{References}

1. Sultan, M.; Miyazaki, T. Energy-Efficient Air-Conditioning Systems for Nonhuman Applications. Refrigeration 2017. [CrossRef]

2. Sultan, M.T.; Miyazaki, T.; Saha, B.B.; Koyama, S. Steady-state investigation of water vapor adsorption for thermally driven adsorption based greenhouse air-conditioning system. Renew. Energy 2016, 86, 785-795. [CrossRef]

3. Sultan, M.; El-Sharkawy, I.I.; Miyazaki, T.; Saha, B.B.; Koyama, S. An overview of solid desiccant dehumidification and air conditioning systems. Renew. Sustain. Energy Rev. 2015, 46, 16-29. [CrossRef]

4. Sultan, M.; Miyazaki, T.; Koyama, S.; Khan, Z.M. Performance evaluation of hydrophilic organic polymer sorbents for desiccant air-conditioning applications. Adsorpt. Sci. Technol. 2017, 36, 311-326. [CrossRef]

5. Sultan, M.; I El-Sharkaw, I.; Miyazaki, T.; Saha, B.B.; Koyama, S. Experimental Study on Carbon Based Adsorbents for Greenhouse Dehumidification. Evergreen 2014, 1, 5-11. [CrossRef]

6. Mahmood, M.H.; Sultan, M.; Miyazaki, T.; Koyama, S. Desiccant Air-Conditioning System for Storage of Fruits and Vegetables: Pakistan Preview. Evergreen 2016, 3, 12-17. [CrossRef] 
7. Mahmood, M.H.; Sultan, M.; Miyazaki, T.; Koyama, S.; Maisotsenko, V.S. Overview of the Maisotsenko cycle-A way towards dew point evaporative cooling. Renew. Sustain. Energy Rev. 2016, 66, 537-555. [CrossRef]

8. Cheng, F.; Li, Y.; Zhang, X.; Li, X. Effect of different absorbents on actual performance of the absorption air-conditioning system based on capacitive deionization regeneration method. Appl. Therm. Eng. 2020, 172, 115130. [CrossRef]

9. Caliskan, H.; Dincer, I.; Hepbasli, A. Exergetic and sustainability performance comparison of novel and conventional air cooling systems for building applications. Energy Build. 2011, 43, 1461-1472. [CrossRef]

10. Zhan, C.; Duan, Z.; Zhao, X.; Smith, S.; Jin, H.; Riffat, S. Comparative study of the performance of the M-cycle counter-flow and cross-flow heat exchangers for indirect evaporative cooling-Paving the path toward sustainable cooling of buildings. Energy 2011, 36, 6790-6805. [CrossRef]

11. Pérez-Lombard, L.; Ortiz, J.; Pout, C. A review on buildings energy consumption information. Energy Build. 2008, 40, 394-398. [CrossRef]

12. Xuan, Y.; Xiao, F.; Niu, X.; Huang, X.; Wang, S. Research and application of evaporative cooling in China: A review (I)-Research. Renew. Sustain. Energy Rev. 2012, 16, 3535-3546. [CrossRef]

13. Kashif, M.; Sultan, M.; Khan, Z.M. Alternative Air-Conditioning Options for Developing Countries. Eur. J. Eng. Res. Sci. 2017, 2, 76-79. [CrossRef]

14. Matsui, K.; Thu, K.; Miyazaki, T. A hybrid power cycle using an inverted Brayton cycle with an indirect evaporative device for waste-heat recovery. Appl. Therm. Eng. 2020, 170, 115029. [CrossRef]

15. Duan, Z.; Zhan, C.; Zhang, X.; Mustafa, M.; Zhao, X.; Alimohammadisagvand, B.; Hasan, A. Indirect evaporative cooling: Past, present and future potentials. Renew. Sustain. Energy Rev. 2012, 16, 6823-6850. [CrossRef]

16. Sultan, M.; Niaz, H.; Miyazaki, T. Investigation of Desiccant and Evaporative Cooling Systems for Animal Air-Conditioning. Low Temp. Technol. 2020. [CrossRef]

17. Maheshwari, G.; Al-Ragom, F.; Suri, R. Energy-saving potential of an indirect evaporative cooler. Appl. Energy 2001, 69, 69-76. [CrossRef]

18. Pandelidis, D.; Anisimov, S. Numerical analysis of the heat and mass transfer processes in selected M-Cycle heat exchangers for the dew point evaporative cooling. Energy Convers. Manag. 2015, 90, 62-83. [CrossRef]

19. Enteria, N.; Mizutani, K. The role of the thermally activated desiccant cooling technologies in the issue of energy and environment. Renew. Sustain. Energy Rev. 2011, 15, 2095-2122. [CrossRef]

20. Pandelidis, D.; Anisimov, S.; Worek, W.M. Comparison study of the counter-flow regenerative evaporative heat exchangers with numerical methods. Appl. Therm. Eng. 2015, 84, 211-224. [CrossRef]

21. Lin, J.; Wang, R.; Li, C.; Wang, S.; Long, J.; Chua, K.J. Towards a thermodynamically favorable dew point evaporative cooler via optimization. Energy Convers. Manag. 2020, 203, 112224. [CrossRef]

22. Arun, B.; Mariappan, V.; Maisotsenko, V.S. Experimental study on combined low temperature regeneration of liquid desiccant and evaporative cooling by ultrasonic atomization. Int. J. Refrig. 2020, 112, 100-109. [CrossRef]

23. Anisimov, S.; Pandelidis, D.; Jedlikowski, A.; Polushkin, V. Performance investigation of a M (Maisotsenko)-cycle cross-flow heat exchanger used for indirect evaporative cooling. Energy 2014, 76, 593-606. [CrossRef]

24. Delgado, J.M.P.Q.; de Lima, A.G.B.; da Silva, M.V. Numerical Analysis of Heat and Mass Transfer in Porous Media; Springer: Berlin/Heidelberg, Germany, 2012. [CrossRef]

25. Khalatov, A.; Karp, I.; Isakov, B. Prospects of the maisotsenko thermodynamic cycle application in ukraine. Int. J. Energy Clean Environ. 2011, 12, 141-157. [CrossRef]

26. Anisimov, S.; Pandelidis, D. Heat- and mass-transfer procesess in indirect evaporative air conditioners through the maisotsenko cycle. Int. J. Energy Clean Environ. 2011, 12, 273-286. [CrossRef]

27. Tertipis, D.; Rogdakis, E. Maisotsenko cycle: Technology overview and energy-saving potential in cooling systems. Energy Emiss. Control. Technol. 2015, 2015, 15. [CrossRef]

28. Anisimov, S.; Pandelidis, D.; Danielewicz, J. Numerical analysis of selected evaporative exchangers with the Maisotsenko cycle. Energy Convers. Manag. 2014, 88, 426-441. [CrossRef]

29. Chua, K.; Chou, S.; Yang, W.; Yan, J. Achieving better energy-efficient air conditioning-A review of technologies and strategies. Appl. Energy 2013, 104, 87-104. [CrossRef] 
30. Anisimov, S.; Pandelidis, D. Numerical study of perforated indirect evaporative air cooler. Int. J. Energy Clean Environ. 2011, 12, 239-250. [CrossRef]

31. Kojok, F.; Fardoun, F.; Younes, R.; Outbib, R. Hybrid cooling systems: A review and an optimized selection scheme. Renew. Sustain. Energy Rev. 2016, 65, 57-80. [CrossRef]

32. Noor, S.; Ashraf, H.; Sultan, M.; Khan, Z.M. Evaporative cooling options for building air-conditioning: A comprehensive study for climatic conditions of Multan (Pakistan). Energies 2020, 13, 3061. [CrossRef]

33. Duan, Z.; Zhao, X.; Zhan, C.; Dong, X.; Chen, H. Energy saving potential of a counter-flow regenerative evaporative cooler for various climates of China: Experiment-based evaluation. Energy Build. 2017, 148, 199-210. [CrossRef]

34. Liu, Y.; Yang, X.; Li, J.; Zhao, X. Energy savings of hybrid dew-point evaporative cooler and micro-channel separated heat pipe cooling systems for computer data centers. Energy 2018, 163, 629-640. [CrossRef]

35. Farmahini-Farahani, M.; Delfani, S.; Esmaeelian, J. Exergy analysis of evaporative cooling to select the optimum system in diverse climates. Energy 2012, 40, 250-257. [CrossRef]

36. Lin, J.; Bui, D.T.; Wang, R.; Chua, K. On the exergy analysis of the counter-flow dew point evaporative cooler. Energy 2018, 165, 958-971. [CrossRef]

37. Alklaibi, A. Experimental and theoretical investigation of internal two-stage evaporative cooler. Energy Convers. Manag. 2015, 95, 140-148. [CrossRef]

38. Fikri, B.; Sofia, E.; Putra, N. Experimental analysis of a multistage direct-indirect evaporative cooler using a straight heat pipe. Appl. Therm. Eng. 2020, 171, 115133. [CrossRef]

39. Khalajzadeh, V.; Farmahini-Farahani, M.; Heidarinejad, G. A novel integrated system of ground heat exchanger and indirect evaporative cooler. Energy Build. 2012, 49, 604-610. [CrossRef]

40. Chauhan, S.S.; Rajput, S. Experimental analysis of an evaporative-vapour compression based combined air conditioning system for required comfort conditions. Appl. Therm. Eng. 2017, 115, 326-336. [CrossRef]

41. Duan, Z.; Zhao, X.; Liu, J.; Zhang, Q. Dynamic simulation of a hybrid dew point evaporative cooler and vapour compression refrigerated system for a building using EnergyPlus. J. Build. Eng. 2019, 21, 287-301. [CrossRef]

42. Zhou, S.; Gong, L.; Liu, X.; Shen, S. Mathematical modeling and performance analysis for multi-effect evaporation/multi-effect evaporation with thermal vapor compression desalination system. Appl. Therm. Eng. 2019, 159, 113759. [CrossRef]

43. Fekadu, G.; Subudhi, S. Renewable energy for liquid desiccants air conditioning system: A review. Renew. Sustain. Energy Rev. 2018, 93, 364-379. [CrossRef]

44. Qi, R.; Dong, C.; Zhang, L.-Z. A review of liquid desiccant air dehumidification: From system to material manipulations. Energy Build. 2020, 215, 109897. [CrossRef]

45. Sultan, M.; Miyazaki, T.; Koyama, S. Optimization of adsorption isotherm types for desiccant air-conditioning applications. Renew. Energy 2018, 121, 441-450. [CrossRef]

46. Mahmood, M.H.; Sultan, M.; Miyazaki, T. Experimental evaluation of desiccant dehumidification and air-conditioning system for energy-efficient storage of dried fruits. Build. Serv. Eng. Res. Technol. 2019, 41, 454-465. [CrossRef]

47. Sultan, M.; Miyazaki, T.; Mahmood, M.H.; Khan, Z.M. Solar assisted evaporative cooling based passive air-conditioning system for agricultural and livestock applications. J. Eng. Sci. Technol. 2018, 13, 693-703.

48. Niaz, H.; Sultan, M.; Khan, A.A.; Miyazaki, T.; Feng, Y.; Khan, Z.M. Study on evaporative cooling assisted desiccant air conditioning system for livestock application in Pakistan. Fresenius Environ. Bull. 2019, 28, 8623-8633.

49. Kashif, M.; Niaz, H.; Sultan, M.; Miyazaki, T.; Feng, Y.; Usman, M.; Shahzad, M.W.; Niaz, Y.; Waqas, M.M.; Ali, I. Study on Desiccant and Evaporative Cooling Systems for Livestock Thermal Comfort: Theory and Experiments. Energies 2020, 13, 2675. [CrossRef]

50. Nagaya, K.; Senbongi, T.; Li, Y.; Zheng, J.; Murakami, I. High energy efficiency desiccant assisted automobile air-conditioner and its temperature and humidity control system. Appl. Therm. Eng. 2006, 26, 1545-1551. [CrossRef]

51. Lee, S.H.; Lee, W.L. Site verification and modeling of desiccant-based system as an alternative to conventional air-conditioning systems for wet markets. Energy 2013, 55, 1076-1083. [CrossRef]

52. Ismail, M.; Angus, D.; Thorpe, G. The performance of a solar-regenerated open-cycle desiccant bed grain cooling system. Sol. Energy 1991, 46, 63-70. [CrossRef] 
53. Guojie, Z.; Chaoyu, Z.; Guanghai, Y.; Chen, W. Development of a New Marine Rotary Desiccant Airconditioning System and its Energy Consumption Analysis. Energy Procedia 2012, 16, 1095-1101. [CrossRef]

54. Zhu, J.; Chen, W. Energy and exergy performance analysis of a marine rotary desiccant air-conditioning system based on orthogonal experiment. Energy 2014, 77, 953-962. [CrossRef]

55. Ascione, F.; Bellia, L.; Capozzoli, A.; Minichiello, F. Energy saving strategies in air-conditioning for museums. Appl. Therm. Eng. 2009, 29, 676-686. [CrossRef]

56. Ascione, F.; Bellia, L.; Capozzoli, A. A coupled numerical approach on museum air conditioning: Energy and fluid-dynamic analysis. Appl. Energy 2013, 103, 416-427. [CrossRef]

57. Daou, K.; Wang, R.; Xia, Z. Desiccant cooling air conditioning: A review. Renew. Sustain. Energy Rev. 2006, 10, 55-77. [CrossRef]

58. La, D.; Dai, Y.; Li, Y.; Wang, R.; Ge, T. Technical development of rotary desiccant dehumidification and air conditioning: A review. Renew. Sustain. Energy Rev. 2010, 14, 130-147. [CrossRef]

59. Mei, L.; Dai, Y. A technical review on use of liquid-desiccant dehumidification for air-conditioning application. Renew. Sustain. Energy Rev. 2008, 12, 662-689. [CrossRef]

60. Saghafifar, M.; Gadalla, M. Innovative inlet air cooling technology for gas turbine power plants using integrated solid desiccant and Maisotsenko cooler. Energy 2015, 87, 663-677. [CrossRef]

61. Gao, W.; Cheng, Y.; Jiang, A.; Liu, T.; Anderson, K. Experimental investigation on integrated liquid desiccant-Indirect evaporative air cooling system utilizing the Maisotesenko-Cycle. Appl. Therm. Eng. 2015, 88, 288-296. [CrossRef]

62. Amer, O.; Boukhanouf, R.; Ibrahim, H.G. A Review of Evaporative Cooling Technologies. Int. J. Environ. Sci. Dev. 2015, 6, 111-117. [CrossRef]

63. Miyazaki, T.; Nikai, I.; Akisawa, A. Simulation analysis of an open-cycle adsorption air conditioning system-numeral modeling of a fixed bed dehumidification unit and the maisotsenko cycle cooling unit. Int. J. Energy Clean Environ. 2011, 12, 341-354. [CrossRef]

64. Yaningsih, I.; Mahmood, M.H.; Wijayanta, A.T.; Miyazaki, T.; Koyama, S. Experimental Study on Dehumidification Technology using Honeycomb Desiccant Block. Evergreen 2018, 5, 11-18. [CrossRef]

65. Kabeel, A. Solar powered air conditioning system using rotary honeycomb desiccant wheel. Renew. Energy 2007, 32, 1842-1857. [CrossRef]

66. Yaningsih, I.; Wijayanta, A.T.; Miyazaki, T.; Koyama, S. Analysis of heat and mass transfer characteristics of desiccant dehumidifier system with honeycomb configuration. Appl. Therm. Eng. 2018, 144, 658-669. [CrossRef]

67. Wrobel, J.; Ma, X.; Schmitz, G.; Grabe, J. A Desiccant Assisted Air Conditioning System with Use of Geothermal Energy. In Proceedings of the World Geothermal Congress, Bali, Indonesia, 25-30 April 2010.

68. Mahmood, M.H.; Sultan, M.; Miyazaki, T. Solid desiccant dehumidification-based air-conditioning system for agricultural storage application: Theory and experiments. Proc. Inst. Mech. Eng. Part A J. Power Energy 2019, 234, 534-547. [CrossRef]

69. ASHRAE. Handbook of Fundamentals; American Society of Heating, Refrigerating and Air-Conditioning Engineers. Inc.: Atlanta, GA, USA, 2013.

70. Sultan, M.; El-Sharkawy, I.I.; Miyazaki, T.; Saha, B.B.; Koyama, S.; Maruyama, T.; Maeda, S.; Nakamura, T. Water vapor sorption kinetics of polymer based sorbents: Theory and experiments. Appl. Therm. Eng. 2016, 106, 192-202. [CrossRef]

71. Esen, H.; Inalli, M.; Esen, M. Technoeconomic appraisal of a ground source heat pump system for a heating season in eastern Turkey. Energy Convers. Manag. 2006, 47, 1281-1297. [CrossRef]

72. Holman, J.P. Experimental Methods for Engineers; McGraw-Hill: New York, NY, USA, 2012.

73. Hepbasli, A.; Akdemir, O. Energy and exergy analysis of a ground source (geothermal) heat pump system. Energy Convers. Manag. 2004, 45, 737-753. [CrossRef]

74. Uçkan, I.; Yılmaz, T.; Hürdoğan, E.; Büyükalaca, O. Experimental investigation of a novel configuration of desiccant based evaporative air conditioning system. Energy Convers. Manag. 2013, 65, 606-615. [CrossRef]

75. Panaras, G.; Mathioulakis, E.; Belessiotis, V. Proposal of a control strategy for desiccant air-conditioning systems. Energy 2011, 36, 5666-5676. [CrossRef] 
76. Sultan, M.; Miyazaki, T.; Saha, B.B.; Koyama, S.; Kil, H.-S.; Nakabayashi, K.; Miyawaki, J.; Yoon, S.-H. Adsorption of Difluoromethane (HFC-32) onto phenol resin based adsorbent: Theory and experiments. Int. J. Heat Mass Transf. 2018, 127, 348-356. [CrossRef]

77. El-Agouz, S.A.; Sathyamurthy, R.; Manokar, A.M. Improvement of humidification-dehumidification desalination unit using a desiccant wheel. Chem. Eng. Res. Des. 2018, 131, 104-116. [CrossRef]

78. Zhang, J.; Ge, T.; Dai, Y.; Zhao, Y.; Wang, R. Experimental investigation on solar powered desiccant coated heat exchanger humidification air conditioning system in winter. Energy 2017, 137, 468-478. [CrossRef]

Publisher's Note: MDPI stays neutral with regard to jurisdictional claims in published maps and institutional affiliations.

(C) 2020 by the authors. Licensee MDPI, Basel, Switzerland. This article is an open access article distributed under the terms and conditions of the Creative Commons Attribution (CC BY) license (http://creativecommons.org/licenses/by/4.0/). 